\title{
Mineralogy of Platinum-Group Elements and Gold in the Ophiolite-Related Placer of the River Bolshoy Khailyk, Western Sayans, Russia
}

\author{
Andrei Y. Barkov ${ }^{1, *}$, Gennadiy I. Shvedov ${ }^{2}$, Sergey A. Silyanov ${ }^{2}$ and Robert F. Martin ${ }^{3}$ \\ 1 Research Laboratory of Industrial and Ore Mineralogy, Cherepovets State University, 5 Lunacharsky \\ Avenue, 162600 Cherepovets, Russia \\ 2 Institute of Mining, Geology and Geotechnology, Siberian Federal University, 95 Avenue Prospekt im. gazety \\ "Krasnoyarskiy Rabochiy", 660025 Krasnoyarsk, Russia; g.shvedov@mail.ru (G.I.S.); \\ silyanov-s@mail.ru (S.A.S.) \\ 3 Department of Earth and Planetary Sciences, McGill University, 3450 University Street, Montreal, \\ QC H3A 0E8, Canada; robert.martin@mcgill.ca \\ * Correspondence: ore-minerals@mail.ru; Tel.: +7-8202-51-78-27
}

Received: 21 May 2018; Accepted: 5 June 2018; Published: 12 June 2018

\begin{abstract}
We describe assemblages of platinum-group minerals (PGM) and associated PGE-Au phases found in alluvium along the River Bolshoy Khailyk, in the western Sayans, Russia. The river drains the Aktovrakskiy ophiolitic complex, part of the Kurtushibinskiy belt, as does the Zolotaya River $\sim 15 \mathrm{~km}$ away, the site of other placer deposits. Three groups of alloy minerals are described: (1) Os-Ir-Ru compositions, which predominate, (2) Pt-Fe compositions of a $\mathrm{Pt}_{3} \mathrm{Fe}$ stoichiometry, and (3) $\mathrm{Pt}-\mathrm{Au}-\mathrm{Cu}$ alloys, which likely crystallized in the sequence from $\mathrm{Au}-(\mathrm{Cu})$-bearing platinum, $\mathrm{Pt}(\mathrm{Au}, \mathrm{Cu}), \mathrm{Pt}(\mathrm{Cu}, \mathrm{Au})$, and $\mathrm{PtAuCu} \mathrm{u}_{2}$, to $\mathrm{PtAu}_{4} \mathrm{Cu}_{5}$. The general trends of crystallization of PGM appear to be: [Os-Ir-Ru alloys] $\rightarrow \mathrm{Pt}_{3}$ Fe-type alloy (with inclusions of $\mathrm{Ru}$-dominant alloy formed by exsolution or via replacement of the host $\mathrm{Pt}-\mathrm{Fe}$ phase) $\rightarrow \mathrm{Pt}-\mathrm{Au}-\mathrm{Cu}$ alloys. We infer that $\mathrm{Rh}$ and $\mathrm{Co}$ mutually substitute for $\mathrm{Fe}$, not $\mathrm{Ni}$, and are incorporated into the pentlandite structure via a coupled mechanism of substitution: $\left[\mathrm{Rh}^{3+}+\mathrm{Co}^{3+}+\square \rightarrow 3 \mathrm{Fe}^{2+}\right]$. Many of the Os-Ir-Ru and $\mathrm{Pt}-\mathrm{Fe}$ grains have porous, fractured or altered rims that contain secondary PGE sulfide, arsenide, sulfarsenide, sulfoantimonide, gold, $\mathrm{Pt}-\mathrm{Ir}-\mathrm{Ni}$-rich alloys, and rarer phases like $\mathrm{Cu}$-rich bowieite and a Se-rich sulfarsenide of Pt. The accompanying pyroxene, chromian spinel and serpentine are highly magnesian, consistent with a primitive ultramafic source-rock. Whereas the alloy phases indicate a highly reducing environment, late assemblages indicate an oxygenated local environment leading to Fe-bearing Ru-Os oxide (zoned) and seleniferous accessory phases.
\end{abstract}

Keywords: platinum-group elements; gold; platinum-group minerals; placer deposits; ophiolite complexes; western Sayans; Russia

\section{Introduction}

It was L.A. Yachevskiy who first found grains of platinum-group minerals (PGM) identified as "osmian iridium" and "platinum" in a placer in 1910 in the Usinskiy area of the western Sayans [1]. These grains, enriched in platinum-group elements (PGE), were recognized in a heavy-mineral concentrate provided by Chirkov, a gold miner. Later, B.M. Porvatov, M.K. Korovin, and N.K. Vysotskiy [1-3] described the geology and occurrences of Au-PGM-bearing placers in the Usinskiy area and other regions of the western Sayans. Krivenko et al. [4] conducted large-scale investigations of associations of PGM in Au-PGE-bearing zones of placers of the Altai-Sayan folded region. Tolstykh et al. [5] reported the occurrence of a highly unusual association of PGM in a placer deposit of the 
Zolotaya River ("Golden River") watershed, located ca. $15 \mathrm{~km}$ from the Bolshoy Khailyk placer. There, arsenotellurides and telluroarsenides of Ir-Os-Ru and an arsenoselenosulfide of Ir occur with a $\mathrm{Pt}-\mathrm{Au}-\mathrm{Cu}$ alloy phase in association with grains of $\mathrm{Os}-\mathrm{Ir}-\mathrm{Ru}$ and $\mathrm{Pt}-\mathrm{Fe}$ alloys. These placer occurrences were attributed to lode serpentinite rocks of the Kurtushibinskiy ophiolite belt [5]. In addition, G.I. Shvedov and V.V. Nekos [6] found grains of placer PGM at the River Bolshoy Khailyk.

In the Aktovrakskiy complex [7], which forms part of the Kurtushibinskiy belt in Krasnoyarskiy kray (Figure 1), serpentitite bodies are fairly abundant at Bolshoy Khailyk, the site of our investigation. The area largely consists of volcanogenic and sedimentary rocks of the Chinginskaya suite of Lower Cambrian age, discordantly overlain by Ordovician "terrigenous" rocks. Dikes and intrusive bodies of Devonian rocks (granite, diorite, and metagabbroic rocks) are considered responsible for placer gold in the area.

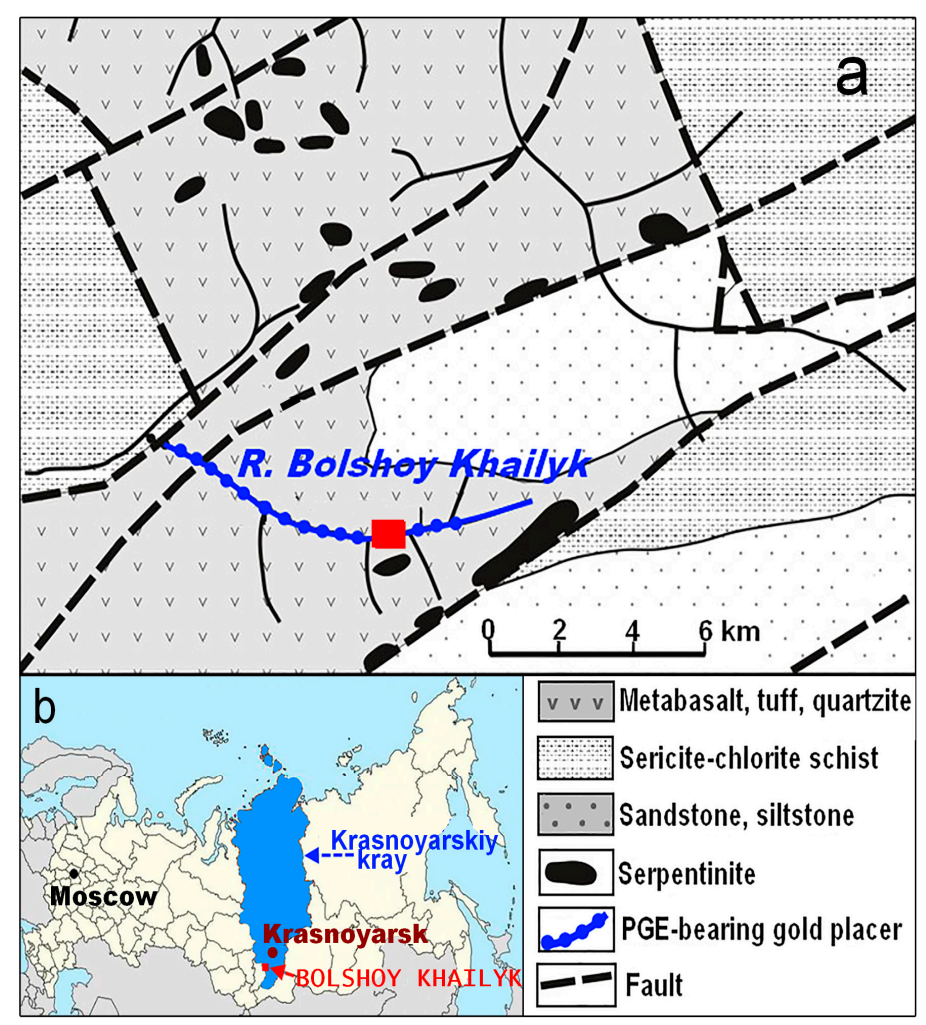

Figure 1. Regional geology of the Bolshoy Khailyk area (a) based on [6], with minor modifications, and a map (b) showing the location of the placer area in the Russian Federation. The red square (a) shows the sampling area (this study).

Our aims in the present article are to document the occurrences and mineralogical characteristics of assemblages of PGM and PGE-Au-rich phases in the alluvial placer associated with the River Bolshoy Khailyk (Figure 1), a tributary of the Urbun (Urgun) River, which flows into the River Yenisei. Our results and observations provide genetic implications and insights into the mineral-forming environments and trends of crystallization of the ophiolite-related PGE-Au mineralization at Bolshoy Khailyk.

\section{Materials and Methods}

We have examined numerous PGM grains and micrometric inclusions found in heavy-mineral concentrates collected at thirteen prospecting dug pits at a smooth bend along the riverbed of Bolshoy Khailyk, within the mining concession outlined (Figure 1). The concentrates are invariably enriched in 
grains of chromian spinel ( $15-75 \mathrm{vol} \%$ ), magnetite (up to $\sim 30 \%$ ), clinopyroxene and amphiboles (up to $\sim 20 \%$ each), with subordinate amounts $(<5 \%)$ of epidote, zoisite, and grossular-rich garnet.

Among the detrital grains of PGM, the Os-Ir-Ru alloy minerals strongly predominate ( $\sim 80 \mathrm{vol} \%)$. Grains of these alloys vary in size from $<0.5$ to $\sim 2 \mathrm{~mm}$ across. Commonly, they display a well-preserved hexagonal outline (Figure 2) and are composed of intergrowths of crystals of varying compositions (e.g., Figure 3b,f). Variously rounded grains also are present, however (Figure 3e).

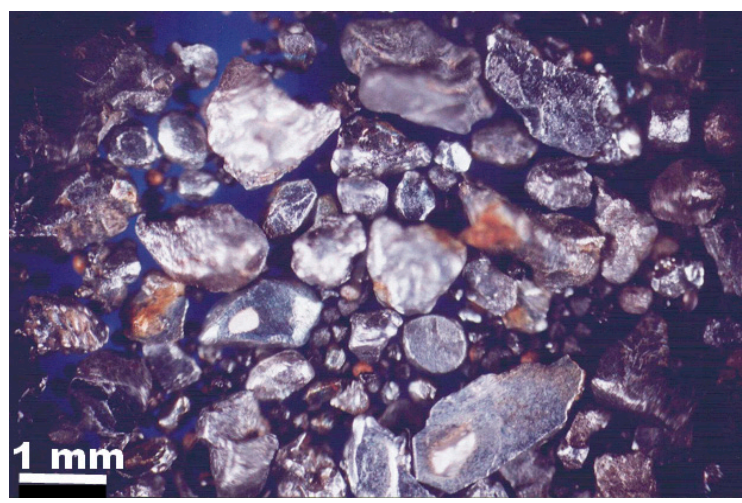

Figure 2. Photo of a concentrate of platinum-group minerals collected in the Bolshoy Khailyk placer deposit. The brownish film present on the surface of some grains represents iron hydroxides.

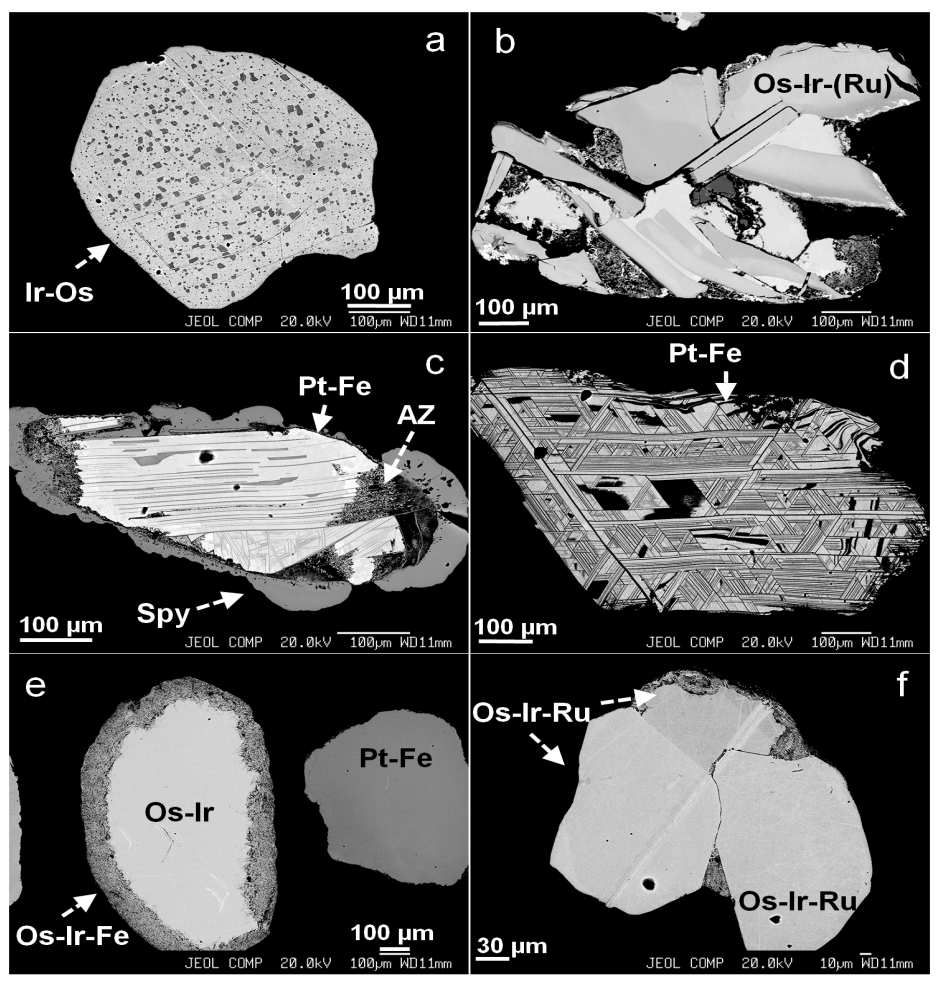

Figure 3. Back-scattered electron (BSE) images showing characteristic textures of placer grains of platinum-group minerals from the Bolshoy Khailyk placer. (a) A partly rounded grain of Ir-Os alloy contains inclusions of Pt-Fe alloy. (b,f) Intergrowths of subhedral crystals of Os-Ir-Ru alloys. (c) A placer grain of Pt-Fe alloy hosting abundant lamellae of Ru-rich alloy (gray) is surrounded by a rim of sperrylite, Spy. Note the existence of a zone of metasomatic alteration (labeled AZ). (d) A subhedral crystal of Pt-Fe alloy displays a perfectly developed rhombohedral cleavage, accompanied by voids. (e) A rounded grain of Os-Ir alloy consists of a rim of Fe-enriched alloy phase of Os-Ir-Fe; note that this rim is very porous and fractured. 
Grains of $\mathrm{Pt}-\mathrm{Fe}$ alloy with a $\mathrm{Pt}_{3} \mathrm{Fe}$-type stoichiometry (i.e., isoferroplatinum or ferroan platinum) account for up to $20 \mathrm{vol} \%$ in the samples examined; the prefix "ferroan" is used here to conform to the historically used name, without implication as to the valence of iron. The size of the Pt-Fe alloy grains, 2.5-3 mm across, generally exceeds that of the associated Os-Ir-Ru alloys. Commonly, these grains are anhedral. Nevertheless, subhedral to euhedral grains of Pt-Fe alloy are also encountered occasionally. The grain shown in Figure $3 \mathrm{~d}$ has a perfectly developed rhombohedral cleavage, with rhombic patterns or voids. Lamellae of Ru-dominant alloy are hosted by the Pt-Fe alloy matrix (Figure $4 \mathrm{~b}$ ); this alloy phase of Ru can also display a rhombic shape, which conforms to the observed cleavage (Figure 5a), and is likely pseudomorphically formed as a result of late replacement of the $\mathrm{Pt}_{3} \mathrm{Fe}$ host.

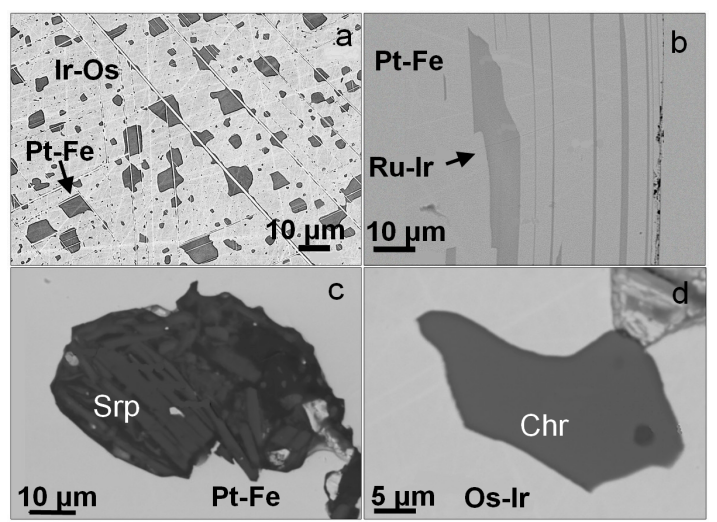

Figure 4. (a) BSE image showing exsolution phases of Pt-Fe alloy hosted by a grain of Ir-Os alloy. Note the presence of an Or-Ir alloy of late generation, cutting the exsolution lamellae of Pt-Fe alloy; this late alloy filled the cleavage space at a subsolidus stage. (b) BSE image of lamellar inclusions of a Ru-dominant alloy, labeled Ru-Ir, which has the composition [ $\mathrm{Ru}_{65.6} \operatorname{Ir}_{12.5} \mathrm{Os}_{9.6} \mathrm{Rh}_{6.7} \mathrm{Pt}_{5.7}$, and is hosted by an isoferroplatinum-type alloy of $\mathrm{Pt}-\mathrm{Fe}$ : $\left[\mathrm{Pt}_{63.4} \mathrm{Fe}_{24.8} \mathrm{Rh}_{6.0} \mathrm{Cu}_{3.6} \mathrm{Pd}_{2.2}\right.$. (c) BSE image of inclusion of serpentine (Srp) hosted by a Pt-Fe alloy, $\left[\mathrm{Pt}_{68.6} \mathrm{Fe}_{23.9} \mathrm{Cu}_{3.7} \mathrm{Pd}_{2.8} \mathrm{Rh}_{1.0}\right]$. (d) Inclusion of a chromian spinel, labeled $\mathrm{Chr}$, which corresponds to magnesiochromite, and is hosted by a placer grain of Os-Ir alloy $\left[\mathrm{Os}_{45.0} \operatorname{Ir}_{39.7} \mathrm{Ru}_{15.3}\right]$; BSE image.
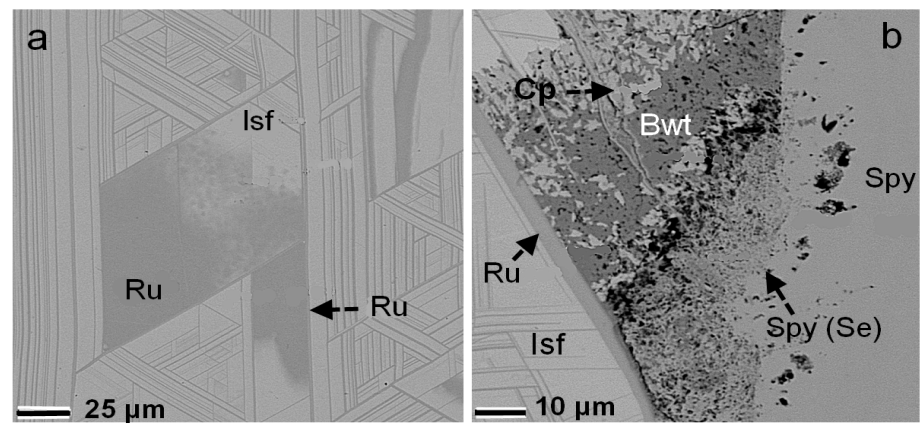

Figure 5. (a) BSE image showing exsolution lamellae of Ru-dominant alloy, labeled $\mathrm{Ru}$ $\left[\mathrm{Ru}_{70.2-72.4} \mathrm{Rh}_{7.1-7.7} \mathrm{Os}_{7.5-7.8} \mathrm{Pt}_{6.1-6.9} \mathrm{Ir}_{5.9-6.1} \mathrm{Fe}_{0.7-1.6}\right]$, hosted by a phase of Pt-Fe alloy related to isoferroplatinum (Isf): $\mathrm{Pt}_{64.3} \mathrm{Fe}_{24.3} \mathrm{Rh}_{7.6} \mathrm{Cu}_{2.3} \mathrm{Ni}_{1.4}$. (b) BSE image displaying the texture and mineral assemblage developed in a zone of metasomatic alteration (labeled AZ in Figure 3c), which consists of secondary phases: bowieite rich in $\mathrm{Cu}$, Bwt $\left[\left(\mathrm{Rh}_{0.70} \mathrm{Pt}_{0.65} \mathrm{Cu}_{0.61} \mathrm{Ru}_{0.05}\right)_{\Sigma 2.01}\left(\mathrm{~S}_{2.83} \mathrm{As}_{0.16}\right)_{\Sigma 2.99}\right]$, cooperite, $\mathrm{Cp}\left[\left(\mathrm{Pt}_{0.88} \mathrm{Rh}_{0.04}\right)_{\Sigma 0.92} \mathrm{~S}_{1.08}\right]$ and a seleniferous variety of sperrylite, Spy-(Se) $\left[\left(\mathrm{Pt}_{0.54} \mathrm{Rh}_{0.45}\right)_{\Sigma 0.99}\left(\mathrm{As}_{1.29} \mathrm{Se}_{0.40} \mathrm{~S}_{0.31}\right)_{\Sigma 2.00}\right]$. This alteration occurs locally, close to the margin of the placer grain of isoferroplatinum, Isf $\left[\left(\mathrm{Pt}_{2.47} \mathrm{Rh}_{0.25} \mathrm{Pd}_{0.09}\right)_{\Sigma 2.8}\left(\mathrm{Fe}_{0.99} \mathrm{Cu}_{0.15} \mathrm{Ni}_{0.05}\right)_{\Sigma 1.2}\right]$, and in contact with the outer rim of Se-free sperrylite, Spy $\left(\mathrm{Pt}_{0.98} \mathrm{Rh}_{0.01}\right)_{\Sigma 0.99}\left(\mathrm{As}_{1.87} \mathrm{~S}_{0.12} \mathrm{Te}_{0.02}\right)_{\Sigma 2.01}$. Note the presence of lamellae composed of a Ru-dominant alloy, labeled $\mathrm{Ru}\left[\mathrm{Ru}_{68.3} \operatorname{Ir}_{12.0} \mathrm{Os}_{7.2} \mathrm{Rh}_{6.9} \mathrm{Pt}_{5.7}\right]$. 
Many of placer grains of Os-Ir-Ru and Pt-Fe alloys have a porous (Figure 3e), abundantly fractured or altered rim (Figure $6 b, c)$, associated with the development of secondary phases of PGE sulfide, arsenide, sulfarsenide, native gold and a Pt-Ir-Ni-rich alloy. Such zones of metasomatic alteration (labeled AZ: Figures $3 c$ and $5 b$ ) are developed close to grain margins; they are isolated and surrounded by an outer rim of sperrylite. The rare compounds formed in these zones include Cu-rich bowieite and a Se-rich sulfarsenide of Pt (Figure 5b).

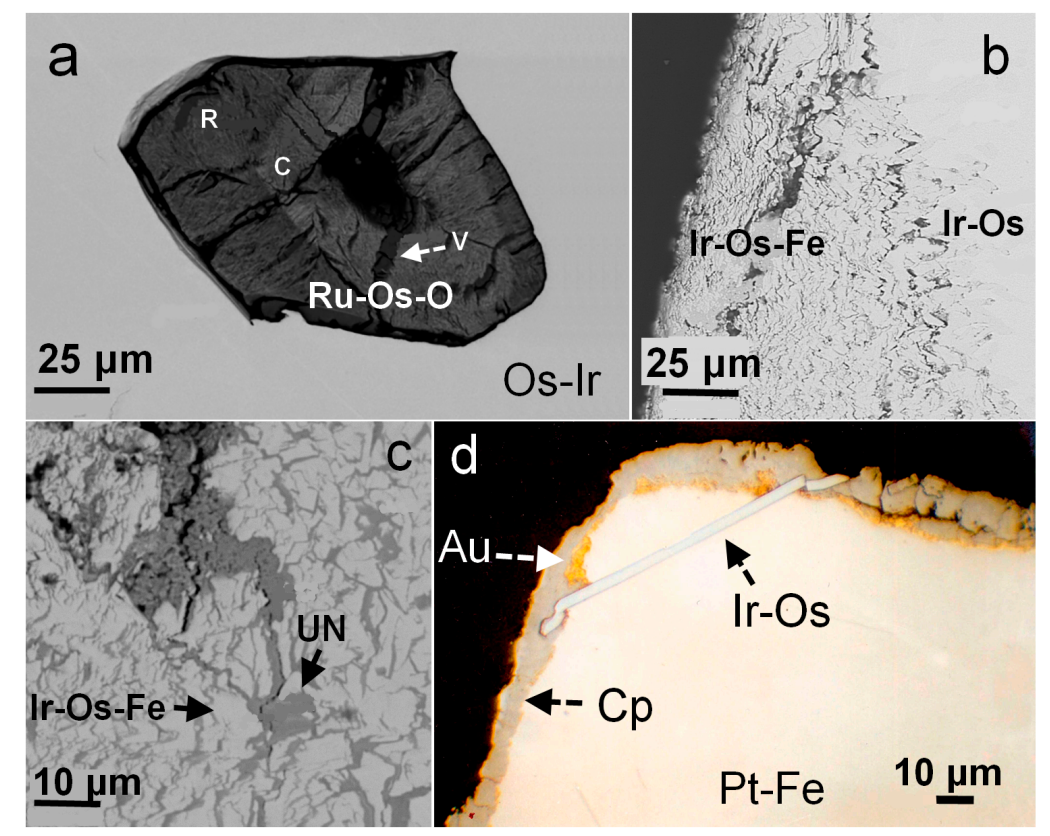

Figure 6. (a) BSE image of a zoned grain of Fe-bearing Ru-Os oxide, labeled Ru-Os-O, which is hosted by Os-Ir alloy [Os $\left.{ }_{45.9} \mathrm{Ir}_{44.2} \mathrm{Ru}_{9.9}\right]$. The letter $\mathrm{C}$ refers to the point analysis of the core zone, the letter $\mathrm{R}$ to that of the rim, and the letter $\mathrm{V}$ to the veinlet. (b) BSE image showing a porous and fractured rim (labeled Ir-Os-Fe) relatively enriched in $\mathrm{Fe}$ and $\mathrm{Ni}$, that is developed around a placer grain of Ir-Os alloy poor in Fe (0.5 wt \% Fe), with the following composition: [ $\left.\operatorname{Ir}_{60.3} \mathrm{Os}_{32.4} \mathrm{Ru}_{3.8} \mathrm{Rh}_{1.7} \mathrm{Fe}_{1.7} \mathrm{Pt}_{0.1}\right]$. The rim contains $5.3 \mathrm{wt} \% \mathrm{Fe}, 0.88 \mathrm{wt} \% \mathrm{Ni}$, and corresponds to $\left[\mathrm{Ir}_{48.6} \mathrm{Os}_{29.8} \mathrm{Fe}_{15.6} \mathrm{Ru}_{3.4} \mathrm{Ni}_{2.5}\right]$. (c) BSE image of veinlets composed of unnamed alloys, labeled UN [( $\left.\mathrm{Ir}, \mathrm{Pt})(\mathrm{Ni}, \mathrm{Fe}, \mathrm{Cu})_{3}-(\mathrm{Pt}, \mathrm{Ir})(\mathrm{Ni}, \mathrm{Fe}, \mathrm{Cu})_{3}\right]$, which are hosted by an Ir-Os-Fe alloy rich in $\mathrm{Fe}(8.0 \mathrm{wt} \%)$ and $\mathrm{Ni}(1.8 \mathrm{wt} \%)\left[\mathrm{Ir}_{48.4} \mathrm{Os}_{24.7} \mathrm{Fe}_{22.3} \mathrm{Ni}_{4.7}\right]$; the latter alloy phase forms the rim (b). (d) Optical photograph showing the development of a composite rim, composed of cooperite $(\mathrm{Cp})\left[\left(\mathrm{Pt}_{0.93} \mathrm{Pd}_{0.02}\right) \mathrm{S}_{1.05}\right]$ and $\mathrm{Au}-\mathrm{Ag}$ alloy, labeled $\mathrm{Au}\left[\mathrm{Au}_{75.3} \mathrm{Ag}_{22.5} \mathrm{Cu}_{2.2}\right]$. Note the presence of a staple-like phase of Ir-Os alloy [ $\operatorname{Ir}_{50.7} \mathrm{Os}_{26.3} \mathrm{Ru}_{8.5} \mathrm{Fe}_{6.5} \mathrm{Pt}_{3.6} \mathrm{Ni}_{2.9} \mathrm{Rh}_{1.4}$ ]. These phases occur in the narrow rim around a grain of $\mathrm{Pt}-\mathrm{Fe}$ alloy $\left[\mathrm{Pt}_{65.4} \mathrm{Fe}_{25.5} \mathrm{Rh}_{3.2} \mathrm{Ir}_{3.1} \mathrm{Pd}_{2.5} \mathrm{Os}_{0.2} \mathrm{Ni}_{0.1}\right]$.

In addition, our materials contain micrometric inclusions of clinopyroxene, chromian spinel, amphiboles, serpentine and base-metal sulfides. We also examined compositional variations in one unusual grain $\sim 2 \mathrm{~mm}$ across, composed of the phase $\mathrm{PtAu}_{4} \mathrm{Cu}_{5}$ with inclusions of other intermetallic compounds of the system $\mathrm{Pt}-\mathrm{Cu}-\mathrm{Au}$, of an unnamed $\mathrm{Pt}-\mathrm{Cu}$ stannide and a Co-Rh-rich pentlandite (Figure 7a,b). 

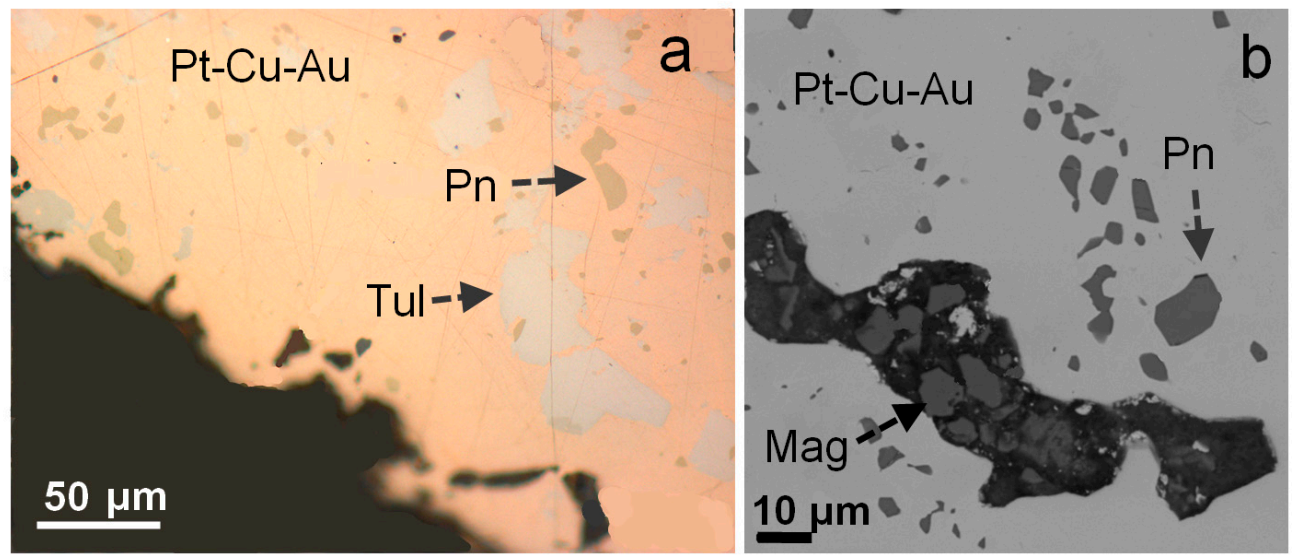

Figure 7. (a) Optical photograph showing inclusions of the tulameenite-ferronickelplatinum series (Tul) and of pentlandite (Pn), which are hosted by a placer grain of $\mathrm{Pt}-\mathrm{Au}-\mathrm{Cu}$ alloy. (b) BSE image of subhedral inclusions of $\mathrm{Co}-\mathrm{Rh}-$ rich pentlandite (Pn) enclosed within the $\mathrm{Pt}-\mathrm{Au}-\mathrm{Cu}$ alloy. Mag is magnetite.

In this study, we used essentially the same approach and analytical facilities as in the complementary project, devoted also to associations of PGM of the Sayan region [8]. Compositions of various PGE alloys, PGM, PGE- and Au-rich phases, silicate minerals and hydrous silicates were investigated with wavelength-dispersive analysis (WDS) using a Camebax-micro electron microprobe (CAMECA SAS, Gennevilliers Cedex, France) at the Sobolev Institute of Geology and Mineralogy, Russian Academy of Sciences, Novosibirsk, Russia. The analytical conditions used for PGE-rich minerals were the following: $20 \mathrm{kV}$ and $60 \mathrm{nA}$; the $L \alpha$ line was used for $\mathrm{Ir}, \mathrm{Rh}, \mathrm{Ru}, \mathrm{Pt}, \mathrm{Pd}$, and $\mathrm{As}$; the $M \alpha$ line was used for $\mathrm{Os}$ and $\mathrm{Au}$, and the $\mathrm{K} \alpha$ line was used for $\mathrm{S}, \mathrm{Fe}, \mathrm{Ni}, \mathrm{Cu}$, and $\mathrm{Co}$. We used as standards pure metals (for the PGE and $\mathrm{Au}$ ), $\mathrm{CuFeS}_{2}$ (for $\mathrm{Fe}, \mathrm{Cu}$, and $\mathrm{S}$ ), synthetic FeNiCo (for Ni and $\mathrm{Co}$ ), and arsenopyrite (for As). The minimum detection limit is $\leq 0.1 \mathrm{wt} \%$ for results of the WDS analyses. The WDS analyses of chromite, clinopyroxene, and amphiboles were acquired at $20 \mathrm{kV}$ and $40 \mathrm{nA}$, using $\mathrm{K} \alpha$ lines, and the following standards: chromite (for $\mathrm{Fe}, \mathrm{Mg}, \mathrm{Al}$, and $\mathrm{Cr}$ ), ilmenite (Ti), manganiferous garnet (for $\mathrm{Mn}$ ), and synthetic $\mathrm{V}_{2} \mathrm{O}_{5}$ (for $\mathrm{V}$ ). The amphibole analyses were done using diopside (for $\mathrm{Ca}$ ), albite (for $\mathrm{Na}$ ), orthoclase (for $\mathrm{K}$ ), pyrope ( $\mathrm{Mg}, \mathrm{Fe}, \mathrm{Al}$, and $\mathrm{Si}$ ), a glass of diopside composition doped with $2 \mathrm{wt} \% \mathrm{TiO}_{2}$ for $\mathrm{Ti}$, and manganiferous and chromiferous garnets (for $\mathrm{Mn}$ and $\mathrm{Cr}$ ) as standards. For serpentine, we used an olivine standard ( $\mathrm{Mg}, \mathrm{Si}, \mathrm{Fe}$, and $\mathrm{Ni}$ ), as well as diopside (Ca), and, as noted, garnets for $\mathrm{Mn}$ and $\mathrm{Cr}$.

We employed scanning-electron microscopy (SEM) and energy-dispersive analysis (EDS) for the analysis of phases whose grain size is on the order of $\leq 2-5 \mu \mathrm{m}$, or larger. These phases were analyzed at $20 \mathrm{kV}$ and $1.2 \mathrm{nA}$ using a Tescan Vega $3 \mathrm{SBH}$ facility combined with an Oxford X-Act spectrometer (Oxford Instruments, Abingdon, UK) at the Siberian Federal University, Krasnoyarsk, Russia. Pure elements (for the PGE, $\mathrm{Fe}, \mathrm{Cu}$ ), as well as $\mathrm{FeS}_{2}$ (for S), InAs (for As), were used as standards. The $L \alpha$ line was used for As and the PGE, except for $\mathrm{Pt}$ and $\mathrm{Au}(\mathrm{M} \alpha$ line); the $\mathrm{K} \alpha$ line was used for $\mathrm{Fe}, \mathrm{Cu}, \mathrm{Ni}$, Co, and $S$.

\section{Results}

\subsection{Grains of Os-Ir-Ru, Pt-Fe Alloys and Exsolution-Induced Phases}

As noted, the Os-Ir-Ru and Pt-Fe alloy minerals account for $\sim 80 \%$ and $\sim 20$ vol \%, respectively, of the detrital PGM. In contrast to the Os-Ir-Ru alloys at Sisim, eastern Sayans [8], we detect no zonation in these grains of alloy at Bolshoy Khailyk. However, there are significant grain-to-grain variations (Table 1), reflected in differences in contrast in back-scattered electron (BSE) images of 
mutually intergrown grains (Figure 3f). Inclusions of $\mathrm{Pt}-\mathrm{Fe}$ alloy are present in an Os-Ir-Ru alloy matrix, and a Ru-Ir-Os alloy occurs as lamellae hosted in a Pt-Fe alloy (Figure 4a,b and Figure 5a).

Table 1. Compositions of grains of Ru-Os-Ir alloy minerals from the Bolshoy Khailyk placer deposit.

\begin{tabular}{|c|c|c|c|c|c|c|c|c|c|c|c|c|}
\hline$\#$ & & & $\mathbf{R u}$ & Os & Ir & $\mathbf{R h}$ & $\mathbf{P t}$ & $\mathbf{P d}$ & $\mathrm{Fe}$ & $\mathrm{Ni}$ & $\mathrm{Cu}$ & Total \\
\hline 2 & & & 54.8 & 35.36 & 7.04 & bdl & bdl & bdl & 1.77 & 1.07 & bdl & 100 \\
\hline 4 & & & 33.18 & 45.99 & 15.93 & 0.53 & 4.07 & bdl & 0.08 & bdl & bdl & 99.8 \\
\hline 5 & & & 28.47 & 34.94 & 33.18 & 1.8 & 1.24 & bdl & 0.18 & 0.04 & bdl & 99.9 \\
\hline 6 & & Inclusion & 33.21 & 26.78 & 32.78 & 1.89 & 5.5 & bdl & 0.2 & bdl & 0.07 & 100.4 \\
\hline 8 & & & 35.87 & 24.9 & 32.57 & 2.13 & 5.14 & bdl & 0.21 & bdl & bdl & 100.8 \\
\hline 9 & & & 50.46 & 14.38 & 19.36 & 4.53 & 10.64 & bdl & 0.14 & 0.05 & bdl & 99.6 \\
\hline 10 & Os-dominant & Matrix & 10.76 & 68.49 & 17.79 & 0.76 & 2.66 & bdl & 0.06 & bdl & bdl & 100.5 \\
\hline 11 & & & 0.75 & 90.45 & 8.56 & bdl & bdl & bdl & bdl & bdl & bdl & 99.8 \\
\hline 12 & & & 12.59 & 45.96 & 39.68 & 1.24 & 0.55 & bdl & 0.26 & bdl & bdl & 100.3 \\
\hline 13 & & & 4.22 & 53.29 & 40.9 & 0.38 & 0.6 & bdl & 0.14 & 0.06 & 0.13 & 99.7 \\
\hline 17 & & & 0.42 & 57.51 & 42.19 & 0.13 & bdl & bdl & 0.41 & 0.06 & bdl & 100.7 \\
\hline 18 & Ir-dominant & Matrix & 0.43 & 33.37 & 61.59 & 0.19 & 4.23 & bdl & 0.23 & 0.04 & bdl & 100.1 \\
\hline 19 & & & 2.88 & 13.89 & 76.02 & 1.01 & 3.52 & bdl & 0.84 & 0.12 & bdl & 98.3 \\
\hline 20 & & & 0.87 & 6.06 & 81.71 & 0.45 & 8.91 & bdl & 1.77 & 0.18 & bdl & 100 \\
\hline 21 & & & 0.27 & 27.92 & 68.5 & bdl & 2.08 & 0.05 & 0.28 & 0.04 & 0.04 & 99.2 \\
\hline 22 & & & 1.74 & 36.73 & 58.39 & 0.59 & 1.91 & bdl & 0.28 & 0.06 & bdl & 99.7 \\
\hline 23 & & Inclusion & 1.26 & 38.36 & 54.7 & 0.55 & 4.41 & bdl & 0.33 & bdl & bdl & 99.6 \\
\hline 24 & & & 5 & 29.02 & 56.48 & 0.82 & 4.02 & bdl & 2.11 & 1.02 & bdl & 98.5 \\
\hline 25 & & & 5.82 & 30.05 & 51.04 & 0.64 & 6 & bdl & 2.83 & 2.03 & bdl & 98.4 \\
\hline \multicolumn{13}{|c|}{ Atomic proportions (per a total of 100 at \%) } \\
\hline 7 & & & 49.9 & 19.4 & 23.9 & 2.70 & 3.6 & 0 & 0.5 & 0 & 0 & \\
\hline 8 & & & 50.3 & 18.5 & 24.0 & 2.93 & 3.7 & 0 & 0.5 & 0 & 0 & \\
\hline 9 & & & 64.2 & 9.7 & 13.0 & 5.66 & 7.0 & 0 & 0.3 & 0.1 & 0 & \\
\hline 10 & Os-dominant & Matrix & 18.3 & 62.0 & 15.9 & 1.3 & 2.3 & 0 & 0.2 & 0 & 0 & \\
\hline 11 & & & 1.4 & 90.1 & 8.4 & 0.0 & 0.0 & 0 & 0.0 & 0 & 0 & \\
\hline 12 & & & 21.0 & 40.8 & 34.9 & 2.0 & 0.5 & 0 & 0.8 & 0 & 0 & \\
\hline 13 & & & 7.6 & 51.2 & 38.9 & 0.7 & 0.6 & 0 & 0.5 & 0.2 & 0.4 & \\
\hline 14 & & & 1.8 & 78.5 & 18.4 & 0.5 & 0.7 & 0 & 0.2 & 0 & 0 & \\
\hline 15 & & Inclusion & 3.2 & 63.2 & 32.8 & 0.4 & 0.3 & 0 & 0.0 & 0 & 0 & \\
\hline 16 & & & 0.6 & 57.4 & 39.6 & 0.2 & 0.2 & 0 & 2.0 & 0 & 0 & \\
\hline 17 & & & 0.8 & 56.4 & 41.0 & 0.2 & 0.0 & 0 & 1.4 & 0.2 & 0 & \\
\hline 18 & Ir-dominant & Matrix & 0.8 & 33.2 & 60.6 & 0.3 & 4.1 & 0 & 0.8 & 0.1 & 0 & \\
\hline 19 & & & 5.3 & 13.5 & 73.0 & 1.8 & 3.3 & 0 & 2.8 & 0.4 & 0 & \\
\hline 20 & & & 1.6 & 5.8 & 77.2 & 0.8 & 8.3 & 0 & 5.8 & 0.6 & 0 & \\
\hline 21 & & & 0.5 & 28.0 & 68.1 & 0.0 & 2.0 & 0.1 & 1.0 & 0.1 & 0.1 & \\
\hline 22 & & & 3.2 & 36.0 & 56.7 & 1.1 & 1.8 & 0 & 0.9 & 0.2 & 0 & \\
\hline 23 & & Inclusion & 2.3 & 37.9 & 53.4 & 1.0 & 4.2 & 0 & 1.1 & 0 & 0 & \\
\hline 24 & & & 8.5 & 26.3 & 50.7 & 1.4 & 3.6 & 0 & 6.5 & 3.0 & 0 & \\
\hline 25 & & & 9.5 & 26.2 & 44.0 & 1.0 & 5.1 & 0 & 8.4 & 5.7 & $<0.1$ & \\
\hline
\end{tabular}

Note. Results of WDS analyses are listed in weight\%; "bdl" indicates that amounts of elements are below detection limits.

Extremely narrow and linear "lamellae" of Os-Ir-Ru alloy cut the associated inclusions of Pt-Fe alloy and occupy the cleavage plane of some of the Ir-Os-Ru placer grains, thus implying subsolvus conditions of their deposition. Some Ru-dominant phases exhibit a rhombohedral shape (Figure 5a); 
these are likely pseudomorphic and reproduce the characteristic forms of the rhombohedral cleavage in the matrix of $\mathrm{Pt}_{3} \mathrm{Fe}$-type phase. A wire-like inclusion of Ir-Os alloy is noteworthy (Figure 6d).

A strong enrichment in $\mathrm{Ru}$ is detected in lamellar phases, e.g., those in Figure $4 \mathrm{~b}: \mathrm{Ru}_{65.6} \operatorname{Ir}_{12.5} \mathrm{Os}_{9.6}$ $\mathrm{Rh}_{6.7} \mathrm{Pt}_{5.7}$, hosted by the isoferroplatinum-type alloy [ $\left.\mathrm{Pt}_{63.4} \mathrm{Fe}_{24.8} \mathrm{Rh}_{6.0} \mathrm{Cu}_{3.6} \mathrm{Pd}_{2.2}\right]$, or in the lamellae shown in Figure 5a $\left[\mathrm{Ru}_{70.2-72.4} \mathrm{Rh}_{7.1-7.7} \mathrm{Os}_{7.5-7.8} \mathrm{Pt}_{6.1-6.9} \mathrm{Ir}_{5.9-6.1} \mathrm{Fe}_{0.7-1.6}\right]$, enclosed by a Pt-Fe alloy related to isoferroplatinum $\left[\mathrm{Pt}_{64.3} \mathrm{Fe}_{24.3} \mathrm{Rh}_{7.6} \mathrm{Cu}_{2.3} \mathrm{Ni}_{1.4}\right]$. The observed Ru-enrichment is a reflection of relative abundance of $\mathrm{Ru}$ in the ophiolite environment, and points to the accumulation of levels of Ru during crystallization. It appears that Ru behaved somewhat incompatibly during the crystallization of the $\mathrm{Pt}$-Fe alloy. In addition, a relative Rh-enrichment is common in compositions of $\mathrm{Pt}-\mathrm{Fe}$ alloy at Bolshoy Khailyk (Table 2).

Table 2. Compositions of placer grains of isoferroplatinum and inclusions of minerals of the tulameenite-ferronickelplatinum series hosted by a $\mathrm{Pt}-\mathrm{Cu}-\mathrm{Au}$ alloy grain from Bolshoy Khailyk.

\begin{tabular}{|c|c|c|c|c|c|c|c|c|c|c|c|c|c|}
\hline$\#$ & & Pt & Ir & $\mathbf{R h}$ & Pd & $\mathbf{R u}$ & Os & $\mathrm{Fe}$ & $\mathbf{N i}$ & $\mathrm{Cu}$ & $\mathrm{Sb}$ & Sn & Total \\
\hline 1 & Isf & 86.32 & bdl & 0.35 & 2.05 & bdl & bdl & 9.45 & 0.15 & 0.7 & bdl & bdl & 99.0 \\
\hline 2 & & 86.98 & 1.88 & 1.88 & bdl & 0.23 & bdl & 9.05 & 0.05 & 0.17 & bdl & bdl & 100.2 \\
\hline 3 & & 86.22 & 0.14 & 0.96 & 1.22 & 0.08 & bdl & 9.3 & 0.21 & 0.94 & bdl & bdl & 99.1 \\
\hline 4 & & 85.11 & bdl & 1.44 & 1.52 & 0.31 & bdl & 9.03 & 0.33 & 0.84 & bdl & bdl & 98.6 \\
\hline 5 & & 86.38 & 0.14 & 0.72 & 1.12 & 0.04 & bdl & 9.49 & 0.34 & 0.65 & bdl & bdl & 98.9 \\
\hline 6 & & 87.47 & bdl & 0.12 & 1.58 & 0.04 & 0.05 & 9.19 & 0.08 & 0.57 & bdl & bdl & 99.1 \\
\hline 7 & & 88.79 & bdl & 0.29 & 0.46 & 0.05 & 0.07 & 8.77 & 0.13 & 0.33 & bdl & bdl & 98.9 \\
\hline 8 & & 85.89 & bdl & 1.05 & 1.53 & 0.14 & bdl & 8.7 & 0.22 & 1.66 & bdl & bdl & 99.2 \\
\hline 9 & & 85.81 & bdl & 1.53 & 2.49 & bdl & bdl & 9.33 & 0.22 & 0.84 & bdl & bdl & 100.2 \\
\hline 10 & & 91.29 & bdl & 0.13 & 0.27 & bdl & bdl & 8.62 & 0.03 & 0.23 & bdl & bdl & 100.6 \\
\hline 11 & Tul-Fnp & 74.81 & bdl & bdl & bdl & bdl & bdl & 11.9 & 5.6 & 7.03 & bdl & bdl & 99.3 \\
\hline 12 & & 74.28 & bdl & bdl & bdl & bdl & bdl & 11.38 & 4.21 & 8.62 & bdl & bdl & 98.5 \\
\hline 13 & & 76.03 & bdl & bdl & bdl & bdl & bdl & 9.11 & 2.38 & 12.18 & bdl & 0.9 & 100.6 \\
\hline 14 & & 77.31 & bdl & bdl & bdl & bdl & bdl & 11.85 & 4.67 & 8.01 & bdl & bdl & 101.8 \\
\hline 15 & & 77.25 & bdl & bdl & bdl & bdl & bdl & 11.62 & 5.12 & 7.41 & bdl & bdl & 101.4 \\
\hline 16 & & 75.17 & bdl & bdl & bdl & bdl & bdl & 9.85 & 2.66 & 9.62 & 0.77 & 0.95 & 99.0 \\
\hline 17 & & 76.63 & bdl & bdl & bdl & bdl & bdl & 11.86 & 3.77 & 7.97 & bdl & bdl & 100.2 \\
\hline 18 & & 75.7 & bdl & bdl & bdl & bdl & bdl & 11.56 & 4.48 & 7.22 & bdl & bdl & 99.0 \\
\hline 19 & & 76.3 & bdl & bdl & bdl & bdl & bdl & 10.52 & 1.91 & 9.15 & 1.44 & 0.7 & 100.0 \\
\hline 20 & & 76.89 & bdl & bdl & bdl & bdl & bdl & 11.1 & 2.74 & 9.51 & 0.32 & 0.47 & 101.0 \\
\hline \multicolumn{14}{|c|}{ Atomic proportions (per a total of 4 a.p.f.u.) } \\
\hline \# & & $\mathbf{P t}$ & Ir & $\mathbf{R h}$ & Pd & $\mathbf{R u}$ & Os & $\mathrm{Fe}$ & $\mathbf{N i}$ & $\mathrm{Cu}$ & $\mathrm{Sb}$ & Sn & $\mathrm{Cu}+\mathrm{Ni}$ \\
\hline 1 & & 2.73 & 0 & 0.02 & 0.12 & 0 & 0 & 1.04 & 0.02 & 0.07 & 0 & 0 & - \\
\hline 2 & & 2.78 & 0.06 & 0.11 & 0 & 0.01 & 0 & 1.01 & 0.01 & 0.02 & 0 & 0 & - \\
\hline 3 & & 2.72 & 0 & 0.06 & 0.07 & 0 & 0 & 1.03 & 0.02 & 0.09 & 0 & 0 & - \\
\hline 4 & & 2.69 & 0 & 0.09 & 0.09 & 0.02 & 0 & 1.00 & 0.03 & 0.08 & 0 & 0 & - \\
\hline 5 & & 2.74 & 0 & 0.04 & 0.07 & 0 & 0 & 1.05 & 0.04 & 0.06 & 0 & 0 & - \\
\hline 6 & & 2.80 & 0 & 0.01 & 0.09 & 0 & 0 & 1.03 & 0.01 & 0.06 & 0 & 0 & - \\
\hline 7 & & 2.90 & 0 & 0.02 & 0.03 & 0 & 0 & 1.00 & 0.01 & 0.03 & 0 & 0 & - \\
\hline 8 & & 2.70 & 0 & 0.06 & 0.09 & 0.01 & 0 & 0.96 & 0.02 & 0.16 & 0 & 0 & - \\
\hline 9 & & 2.66 & 0 & 0.09 & 0.14 & 0 & 0 & 1.01 & 0.02 & 0.08 & 0 & 0 & - \\
\hline 10 & & 2.97 & 0 & 0.01 & 0.02 & 0 & 0 & 0.98 & 0 & 0.02 & 0 & 0 & - \\
\hline 11 & & 1.91 & 0 & 0 & 0 & 0 & 0 & 1.06 & 0.48 & 0.55 & 0 & 0 & 1.03 \\
\hline 12 & & 1.92 & 0 & 0 & 0 & 0 & 0 & 1.03 & 0.36 & 0.69 & 0 & 0 & 1.05 \\
\hline 13 & & 1.97 & 0 & 0 & 0 & 0 & 0 & 0.82 & 0.20 & 0.97 & 0 & 0.04 & 1.17 \\
\hline 14 & & 1.95 & 0 & 0 & 0 & 0 & 0 & 1.04 & 0.39 & 0.62 & 0 & 0 & 1.01 \\
\hline 15 & & 1.96 & 0 & 0 & 0 & 0 & 0 & 1.03 & 0.43 & 0.58 & 0 & 0 & 1.01 \\
\hline 16 & & 1.99 & 0 & 0 & 0 & 0 & 0 & 0.91 & 0.23 & 0.78 & 0.03 & 0.04 & 1.02 \\
\hline 17 & & 1.98 & 0 & 0 & 0 & 0 & 0 & 1.07 & 0.32 & 0.63 & 0 & 0 & 0.95 \\
\hline 18 & & 1.98 & 0 & 0 & 0 & 0 & 0 & 1.05 & 0.39 & 0.58 & 0 & 0 & 0.97 \\
\hline 19 & & 2.02 & 0 & 0 & 0 & 0 & 0 & 0.97 & 0.17 & 0.74 & 0.06 & 0.03 & 0.91 \\
\hline 20 & & 1.98 & 0 & 0 & 0 & 0 & 0 & 1.00 & 0.23 & 0.75 & 0.01 & 0.02 & 0.99 \\
\hline
\end{tabular}

Note. Numbers 1-10 pertain to results of WDS analyses, \#11-20 to EDS analyses. The label Isf means isoferroplatinum-type alloy; Tul-Fnp are members of the tulameenite-ferronickelplatinum series; "bdl" indicates that amounts of elements are below detection limits. 
Alloy phases of the tulameenite-ferronickelplatinum series ( $\leq 0.1 \mathrm{~mm}$ across) occur as inclusions in the matrix of a ternary $\mathrm{Pt}-\mathrm{Au}-\mathrm{Cu}$ phase (Figure 7a), and show strong variations of composition owing to Ni-for-Cu substitution (Table 2). An intermediate member contains $\sim 0.5 \mathrm{Ni}$ atoms per formula unit (hereafter a.p.f.u.) in this series. In addition, partly subhedral inclusions ( $\leq 20 \mu \mathrm{m}$ in size) of a ferronickelplatinum-type alloy (\#1-3, Table 3) were observed as inclusions in grains of Os-Ir-Ru alloy.

Table 3. Compositions of Ni-enriched alloys of Pt-Ir-Ni-Fe from the Bolshoy Khailyk deposit.

\begin{tabular}{|c|c|c|c|c|c|c|c|c|c|c|}
\hline & $\mathbf{P t}$ & Ir & $\mathbf{R h}$ & $\mathbf{R u}$ & Os & $\mathrm{Fe}$ & $\mathrm{Ni}$ & $\mathrm{Cu}$ & & Total \\
\hline 1 & 76.79 & bdl & 0.46 & bdl & bdl & 8.37 & 12.65 & 2.02 & & 100.29 \\
\hline 2 & 73.89 & bdl & 0.36 & bdl & bdl & 10.08 & 13.54 & 2.28 & & 100.15 \\
\hline 3 & 78.08 & bdl & 0.29 & bdl & bdl & 8.63 & 12.61 & 2.01 & & 101.62 \\
\hline 4 & 51.64 & 5.44 & bdl & bdl & bdl & 12.89 & 27.61 & 2.55 & & 100.13 \\
\hline 5 & 51.64 & 5.4 & bdl & bdl & bdl & 13.3 & 28.29 & 1.62 & & 100.25 \\
\hline 6 & 49.55 & 6.1 & bdl & bdl & bdl & 13.48 & 27.79 & 1.56 & & 98.48 \\
\hline 7 & 52.17 & 5.77 & bdl & bdl & bdl & 12.85 & 27.01 & 1.56 & & 99.36 \\
\hline 8 & 6.28 & 55.12 & bdl & bdl & 2.23 & 11.01 & 25.96 & bdl & & 100.60 \\
\hline 9 & 21.28 & 28.74 & 0.38 & bdl & bdl & 13.88 & 34.83 & 1.9 & & 101.01 \\
\hline 10 & 24.26 & 30.4 & 0.43 & bdl & bdl & 12.91 & 29.87 & 2.05 & & 99.92 \\
\hline 11 & 10.41 & 38.72 & 0.27 & bdl & bdl & 14.17 & 35.42 & bdl & & 98.99 \\
\hline 12 & 14.86 & 32.31 & 0.51 & bdl & bdl & 13.7 & 36.27 & 0.98 & & 98.63 \\
\hline 13 & 13.43 & 48.18 & 0.52 & bdl & bdl & 14.44 & 23.84 & bdl & & 100.41 \\
\hline 14 & 23.86 & 28.35 & 0.44 & bdl & bdl & 14.97 & 31.03 & bdl & & 98.65 \\
\hline 15 & 26.86 & 28.14 & 0.22 & bdl & 2.06 & 13.45 & 30.55 & bdl & & 101.28 \\
\hline 16 & 48.03 & 6.03 & 0.47 & 0.06 & 0.88 & 13.11 & 26.03 & 1.63 & & 96.24 \\
\hline 17 & 49.08 & 6.65 & 0.45 & bdl & 0.3 & 12.91 & 24.5 & 1.44 & & 95.33 \\
\hline 18 & 48.69 & 9.41 & 0.43 & 0.43 & 1.74 & 13.17 & 23.47 & 1.49 & & 98.83 \\
\hline 19 & 13.09 & 36.82 & 0.34 & bdl & 1.62 & 11.57 & 33.38 & 1.71 & & 98.53 \\
\hline 20 & 12.84 & 36.71 & 0.34 & bdl & 1.76 & 11.58 & 33.33 & 1.69 & & 98.25 \\
\hline \multicolumn{11}{|c|}{ Atomic proportions (per a total of 100 at \%) } \\
\hline & $\mathbf{P t}$ & Ir & $\mathbf{R h}$ & $\mathbf{R u}$ & Os & Fe & $\mathbf{N i}$ & $\mathrm{Cu}$ & $\mathrm{Ni} / \mathrm{Fe}$ & $\begin{array}{l}(\mathrm{Ni}+\mathrm{Fe}+ \\
\mathrm{Cu}) / \Sigma \mathrm{PGE}\end{array}$ \\
\hline 1 & 49.5 & 0 & 0.6 & 0 & 0 & 18.8 & 27.1 & 4.0 & 1.44 & 1.00 \\
\hline 2 & 45.7 & 0 & 0.4 & 0 & 0 & 21.8 & 27.8 & 4.3 & 1.28 & 1.17 \\
\hline 3 & 49.8 & 0 & 0.4 & 0 & 0 & 19.2 & 26.7 & 3.9 & 1.39 & 0.99 \\
\hline 4 & 25.6 & 2.7 & 0 & 0 & 0 & 22.3 & 45.5 & 3.9 & 2.04 & 2.53 \\
\hline 5 & 25.5 & 2.7 & 0 & 0 & 0 & 22.9 & 46.4 & 2.5 & 2.02 & 2.55 \\
\hline 6 & 24.8 & 3.1 & 0 & 0 & 0 & 23.5 & 46.2 & 2.4 & 1.96 & 2.59 \\
\hline 7 & 26.4 & 3.0 & 0 & 0 & 0 & 22.7 & 45.5 & 2.4 & 2.00 & 2.40 \\
\hline 8 & 3.3 & 29.6 & 0 & 0 & 1.2 & 20.3 & 45.6 & 0 & 2.24 & 1.93 \\
\hline 9 & 9.6 & 13.2 & 0.3 & 0 & 0 & 21.9 & 52.3 & 2.6 & 2.39 & 3.32 \\
\hline 10 & 11.7 & 14.9 & 0.4 & 0 & 0 & 21.8 & 48.1 & 3.0 & 2.20 & 2.69 \\
\hline 11 & 4.8 & 18.1 & 0.2 & 0 & 0 & 22.8 & 54.1 & 0 & 2.38 & 3.33 \\
\hline 12 & 6.8 & 14.9 & 0.4 & 0 & 0 & 21.7 & 54.8 & 1.4 & 2.52 & 3.53 \\
\hline 13 & 7.0 & 25.3 & 0.5 & 0 & 0 & 26.1 & 41.1 & 0 & 1.57 & 2.05 \\
\hline 14 & 11.4 & 13.8 & 0.4 & 0 & 0 & 25.0 & 49.4 & 0 & 1.97 & 2.91 \\
\hline 15 & 13.0 & 13.8 & 0.2 & 0 & 1.0 & 22.8 & 49.2 & 0 & 2.16 & 2.56 \\
\hline 16 & 24.8 & 3.2 & 0.5 & 0.06 & 0.5 & 23.7 & 44.7 & 2.6 & 1.89 & 2.45 \\
\hline 17 & 26.1 & 3.6 & 0.5 & 0 & 0.2 & 24.0 & 43.3 & 2.4 & 1.81 & 2.30 \\
\hline 18 & 25.6 & 5.0 & 0.4 & 0.44 & 0.9 & 24.2 & 41.0 & 2.4 & 1.70 & 2.08 \\
\hline 19 & 6.3 & 17.8 & 0.3 & 0 & 0.8 & 19.3 & 53.0 & 2.5 & 2.74 & 2.97 \\
\hline 20 & 6.1 & 17.8 & 0.3 & 0 & 0.9 & 19.4 & 53.0 & 2.5 & 2.74 & 2.98 \\
\hline
\end{tabular}

Note. Numbers 1-10 are results of SEM/EDS analyses, and \#16-20 of WDS analyses; "bdl" indicates that amounts of elements are below detection limits.Compositions \#1-3 are close to ferronickelplatinum, \#4-20 are unnamed members of the series $(\mathrm{Pt}, \mathrm{Ir})(\mathrm{Ni}, \mathrm{Fe}, \mathrm{Cu})_{3-x}$ and $(\mathrm{Ir}, \mathrm{Pt})(\mathrm{Ni}, \mathrm{Fe}, \mathrm{Cu})_{3-x}$.

We document the existence at Bolshoy Khailyk of extensive fields of solid solution in the system Os- $\mathrm{Ru}-\mathrm{Ir}$ (Figure 8). The general enrichment in Ru is recognized in the coexisting pairs of matrix and 
exsolution-induced inclusions. As shown for comparison in Figure 8, the Os-Ir-Ru alloy grains from the neighboring placer at the River Zolotaya [5] also display the characteristic pattern of enrichment in $\mathrm{Ru}$.

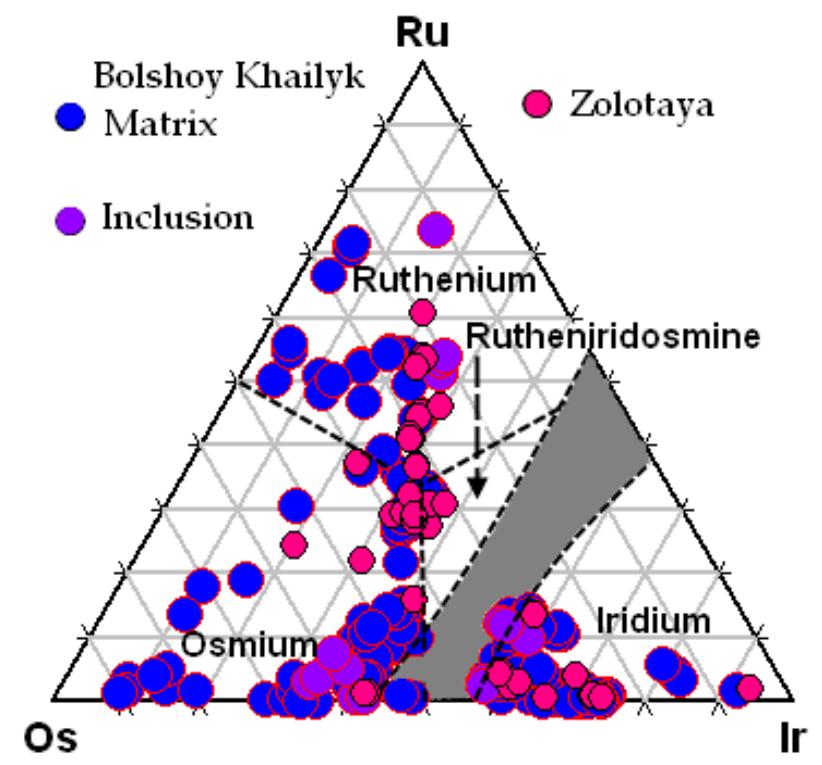

Figure 8. Compositional variations of grains of Os-Ir-Ru alloys from the Bolshoy Khailyk placer (this study), in comparison with alloys from the Zolotaya River deposit, western Sayans [5], in terms of the Os-Ir-Ru diagram (at \%). The miscibility gap and nomenclature are on the basis of [9].

\subsection{Fe-Ni-Enriched Rims and Unnamed Alloys of the Series (Pt,Ir) $(\mathrm{Ni}, \mathrm{Fe}, \mathrm{Cu})_{3-x}-(\mathrm{Ir}, \mathrm{Pt})(\mathrm{Ni}, \mathrm{Fe}, \mathrm{Cu})_{3-x}$}

The porous and fractured rim on grains of Ir-Os-Ru alloy (Figure 3e) is notably enriched in $\mathrm{Fe}$ and $\mathrm{Ni}$ relative to the adjacent phases analyzed beyond the rim. For example, the rim shown in Figure $6 \mathrm{~b}$ has the typical composition: Fe 5.3, Ni 0.9, Ir 56.7, Os 34.4, and Ru 2.1, total $99.4 \mathrm{wt} \%$, corresponding to $\left[\mathrm{Ir}_{48.6} \mathrm{Os}_{29.8} \mathrm{Fe}_{15.6} \mathrm{Ru}_{3.4} \mathrm{Ni}_{2.5}\right.$ ] (in at \%). This rim is developed around an alloy phase that contains: Fe 0.5, Ni <0.1, Ir 62.5, Os 33.2, Ru 2.1, Rh 0.9, Pt 0.1, total 99.3 wt \%, or $\left[\operatorname{Ir}_{60.3} \mathrm{Os}_{32.4} \mathrm{Ru}_{3.8} \mathrm{Rh}_{1.7} \mathrm{Fe}_{1.7} \mathrm{Pt}_{0.1}\right]$. These variations indicate that Fe largely substitutes for Ir in the rim phase. The rim area shown in Figure 6c is even richer in Fe and Ni: Fe 8.0, Ni 1.8, Ir 60.1, Os 30.4, total 100.3 wt \%, or $\left[\operatorname{Ir}_{48.4} \mathrm{Os}_{24.7} \mathrm{Fe}_{22.3} \mathrm{Ni}_{4.7}\right]$.

Interestingly, unnamed alloys of the series $(\mathrm{Pt}, \mathrm{Ir})(\mathrm{Ni}, \mathrm{Fe}, \mathrm{Cu})_{3-x}-(\mathrm{Ir}, \mathrm{Pt})(\mathrm{Ni}, \mathrm{Fe}, \mathrm{Cu})_{3-x}$ occur as veinlets of late phases associated with the Fe-Ni-enriched rim (Figure $6 \mathrm{c}$ ). Their compositions reveal fairly strong variations in Pt-Ir and Ni-Fe-Cu contents (\#4-20, Table 3). These alloy phases are Ni-dominant and contain essential Pt, which could be important to stabilize the structure. Indeed, the $\mathrm{IrNi}_{3}$ phase has not been encountered in synthesis experiments, whereas the ordered phase $\mathrm{PtNi}_{3}$ crystallizes at $580{ }^{\circ} \mathrm{C}$ in the system $\mathrm{Pt}-\mathrm{Ni}[10]$.

\subsection{Ni-Ir-Fe Alloy, Fe-Ni-rich Ir-Os Alloy, and Inclusions of Base-Metal Sufides}

Alloys of Ni-Ir-Fe and Fe-Ni-Ir-Os are associated with a local zone of alteration in a grain of Ir-dominant alloy, which contains Ir 72.2, Os 25.2, Fe 1.6, Rh 0.5, Ru 0.3, total 99.8 wt \%, or $\left[\mathrm{Ir}_{69.0} \mathrm{Os}_{24.3} \mathrm{Fe}_{5.4} \mathrm{Rh}_{0.9} \mathrm{Ru}_{0.5}\right]$. The $\mathrm{Ni}-(\mathrm{Fe})$-rich alloy developed in this assemblage has the following composition: Ir 58.12, Os 9.44, Ni 18.99, Fe 11.47, total 98.0 wt \%, or $\left[\mathrm{Ni}_{36.7} \operatorname{Ir}_{34.3} \mathrm{Fe}_{23.3} \mathrm{Os}_{5.6}\right]$. Its structure remains unknown; it is Ni-dominant and, thus, probably corresponds to garutiite (Ni,Fe,Ir), the hexagonal polymorph of native nickel cf. [11], or to its cubic polymorph, nickel. This phase is devoid of $\mathrm{Pt}$, and differs from alloys of the series $(\mathrm{Pt}, \mathrm{Ir})(\mathrm{Ni}, \mathrm{Fe}, \mathrm{Cu})_{3-x}-(\mathrm{Ir}, \mathrm{Pt})(\mathrm{Ni}, \mathrm{Fe}, \mathrm{Cu})_{3-x}$ by a lower value of $(\mathrm{Ni}+\mathrm{Fe}) / \mathrm{PGE}(1.5)$. Nevertheless, we cannot exclude that it belongs to the latter solid solution. 
One grain of Fe-rich alloy in this altered zone has an Ir-dominant composition: Ir 55.17, Os 30.27, Fe 8.17, $\mathrm{Ni} 4.46, \mathrm{Ru} 0.77$, total 98.8, or [ $\left.\operatorname{Ir}_{42.5} \mathrm{Os}_{23.5} \mathrm{Fe}_{21.6} \mathrm{Ni}_{11.2} \mathrm{Ru}_{1.1}\right]$. Therefore, this phase is enriched strongly in the hexaferrum component, i.e., (Fe,PGE), cf. [12,13].

Micrometric and droplet-shaped inclusions of base-metal sulfides $\leq 10 \mu \mathrm{m}$ in diameter occur close to margin in this grain of Ir-dominant alloy. Three types of phases are recognized on the basis of their compositions. The first is a monosulfide-type phase that contains: Ni 24.6, Fe 24.1, Cu 12.8, S 35.2, total $96.7 \mathrm{wt} \%$, corresponding to the formula $\left(\mathrm{Fe}_{0.40} \mathrm{Ni}_{0.39} \mathrm{Cu}_{0.19}\right)_{\Sigma 0.98} \mathrm{~S}_{1.02}$ calculated for a total of 2 a.p.f.u. A bornite-like phase is with the composition: $\mathrm{Cu}$ 52.1, Fe 16.5, S 28.8, total 97.4 wt \%; its formula is $\left(\mathrm{Cu}_{4.06} \mathrm{Fe}_{1.47}\right)_{\Sigma 5.5} \mathrm{~S}_{4.5}$ (for 10 a.p.f.u.). And the third is represented by a godlevskite-like phase: Ni 70.2, S 30.2, total 100.4 wt \%, or $\mathrm{Ni}_{9.5} \mathrm{~S}_{7.5}$ (for 17 a.p.f.u.).

\subsection{PGE Sulfides, Unnamed $\mathrm{Ni}[\operatorname{Ir}(\mathrm{Co}, \mathrm{Cu}, \mathrm{Fe})]_{2} \mathrm{~S}_{4}$, and Sperrylite}

We analyzed several species of PGE-based sulfides found as inclusions (up to $~ 50 \mu \mathrm{m}$ ) hosted by grains of PGE alloys or as components of the rim or overgrowth on these grains. Results of analyses of ten grains (WDS) indicate that members of the laurite-erlichmanite series are relatively poor in Ir (up to $\sim 10-15 \mathrm{wt} \%$, Table 4 ). The exceptions are minute grains of Ir-rich laurite ( $\leq 5 \mu \mathrm{m}$ across) deposited within a narrow rim that is developed around a grain of Ir-Os alloy; these are associated with members of the tolovkite-irarsite series and native gold [ $\left.\mathrm{Au}_{74.1-91.1} \mathrm{Ag}_{0.9-19.5} \mathrm{Cu}_{6.4-8.1}\right]$. Note that the Au-rich alloy is enriched in $\mathrm{Cu}$, and its composition ranges up to high-purity gold. The Ir-rich laurite is devoid of Os; it has the following composition: Ru 46.1, Ir 19.7, S 35.5, total $101.3 \mathrm{wt} \%$, corresponding to $\left(\mathrm{Ru}_{0.82} \mathrm{Ir}_{0.18}\right)_{\Sigma 1.00} \mathrm{~S}_{1.99}$. The phase could possibly imply conditions of metastable crystallization at a low temperature as a representative of a late-stage assemblage at the rim. Compositions of five grains of cooperite are close to being stoichiometric (\#3,4, Table 4). A grain of bowieite in the zone of deuteric alteration (Figure $5 b)$ is anomalously rich in $\mathrm{Cu}(\# 5$, Table 4).

Table 4. Compositions of various PGE sulfides from the Bolshoy Khailyk deposit.

\begin{tabular}{|c|c|c|c|c|c|c|c|c|c|c|c|c|c|c|}
\hline$\#$ & & $\mathbf{R u}$ & Os & Ir & $\mathbf{R h}$ & $\mathbf{P t}$ & Pd & $\mathrm{Fe}$ & $\mathrm{Ni}$ & Co & $\mathrm{Cu}$ & $\mathrm{S}$ & As & Total \\
\hline 1 & Laurite & 53.3 & 0.61 & 10.03 & 0.37 & bdl & 0.80 & bdl & bdl & bdl & bdl & 35.37 & bdl & 100.48 \\
\hline 2 & & 35.46 & 22.38 & 6.92 & 0.59 & bdl & 0.15 & bdl & bdl & bdl & bdl & 33.2 & bdl & 98.70 \\
\hline 3 & Cooperite & bdl & bdl & bdl & 0.16 & 84.06 & bdl & bdl & 0.22 & bdl & bdl & 15.51 & bdl & 99.95 \\
\hline 4 & & bdl & bdl & bdl & bdl & 82.09 & 0.47 & bdl & 1.22 & bdl & bdl & 15.32 & bdl & 99.10 \\
\hline 5 & Bowieite (Cu-rich) & 1.60 & bdl & bdl & 20.77 & 36.23 & bdl & bdl & bdl & bdl & 11.12 & 26.11 & 3.53 & 99.40 \\
\hline 6 & UN Tsp & bdl & bdl & 42.33 & bdl & bdl & bdl & 4.13 & 12.17 & 6.57 & 4.31 & 26.55 & bdl & 100.11 \\
\hline 7 & & bdl & bdl & 41.93 & bdl & bdl & bdl & 4.15 & 13.93 & 6.38 & 5.5 & 27.62 & bdl & 99.51 \\
\hline 8 & & bdl & bdl & 43.59 & bdl & bdl & bdl & 3.98 & 12.25 & 6.09 & 5.87 & 27.37 & bdl & 99.15 \\
\hline 9 & & bdl & bdl & 43.84 & bdl & bdl & bdl & 4.52 & 12.86 & 6.70 & 5.41 & 27.81 & bdl & 101.14 \\
\hline \multicolumn{15}{|c|}{ Atomic proportions } \\
\hline \# & & $\mathbf{R u}$ & Os & Ir & Rh & Pt & $\mathbf{P d}$ & $\mathrm{Fe}$ & $\mathbf{N i}$ & Co & $\mathrm{Cu}$ & $S$ & As & $\Sigma \mathrm{Me}$ \\
\hline 1 & Laurite & 0.93 & 0.01 & 0.09 & 0.01 & & 0.013 & 0 & 0 & 0 & 0 & 1.95 & 0 & 1.05 \\
\hline 2 & & 0.68 & 0.23 & 0.07 & 0.01 & & 0.003 & 0 & 0 & 0 & 0 & 2.01 & 0 & 0.99 \\
\hline 3 & Cooperite & 0 & 0 & 0 & 0.003 & 0.94 & 0 & 0 & 0.008 & 0 & 0 & 1.05 & 0 & 0.95 \\
\hline 4 & & 0 & 0 & 0 & 0 & 0.91 & 0.01 & 0 & 0.05 & 0 & 0 & 1.03 & 0 & 0.97 \\
\hline 5 & Bowieite & 0.05 & 0 & 0 & 0.70 & 0.65 & 0 & 0 & 0 & 0 & 0.61 & 2.83 & 0.16 & 2.01 \\
\hline 6 & UN Tsp & 0 & 0 & 1.00 & 0 & 0 & 0 & 0.34 & 0.94 & 0.51 & 0.31 & 3.76 & 0 & 3.09 \\
\hline 7 & & 0 & 0 & 0.96 & 0 & 0 & 0 & 0.33 & 1.05 & 0.48 & 0.38 & 3.80 & 0 & 3.20 \\
\hline 8 & & 0 & 0 & 1.02 & 0 & 0 & 0 & 0.32 & 0.94 & 0.46 & 0.42 & 3.84 & 0 & 3.16 \\
\hline 9 & & 0 & 0 & 1.00 & 0 & 0 & 0 & 0.36 & 0.96 & 0.50 & 0.37 & 3.81 & 0 & 3.19 \\
\hline
\end{tabular}

Note. Numbers 1-4 pertain to results of WDS analyses, and \#5-9 are SEM/EDS; "bdl" indicates that amounts of elements are below detection limits. The total of an.\#6 includes $4.05 \mathrm{wt} \% \mathrm{Sb}$, which corresponds to $0.15 \mathrm{Sb}$ a.p.f.u. The atomic proportions were calculated on the basis of a total of 3 a.p.f.u. (for laurite), 2 a.p.f.u. (cooperite), 5 a.p.f.u. (bowieite), and 7 a.p.f.u. for the unnamed phase related to thiospinels (UN Tsp).

We document the existence of an unknown sulfide that presumably is related to thiospinels, as it displays a $\mathrm{Me}_{3} \mathrm{~S}_{4}$ stoichiometry, cf. [14], where Me represents the total content of metals (i.e., Ir, Co, $\mathrm{Fe}$ and $\mathrm{Cu})$. This phase occurs in peripheral portions of irregular grains $(\leq 50 \mu \mathrm{m})$, enclosed within a 
grain of Ir-Os alloy. Its composition corresponds to the formula $\mathrm{Ni}[\operatorname{Ir}(\mathrm{Co}, \mathrm{Cu}, \mathrm{Fe})]_{2} \mathrm{~S}_{4}(\# 6-9$, Table 4). It seems likely that this phase is related to the synthetic thiospinel $\mathrm{NiIr}_{2} \mathrm{~S}_{4}$ [15]; one of the two Ir atoms is presumably replaced by Co at Bolshoy Khailyk. The mixed-valence character of Ir is recognized in PGE thiospinels ([14] and references therein).

A total of 17 data-points (WDS) done on representative grains and inclusions of sperrylite yield normal levels of incorporation of Ir and Rh, up to $\sim 3 \mathrm{wt} \%$ each, and up to $1.8 \mathrm{wt} \% \mathrm{~S}$.

\subsection{Zones of Deuteric Alteration}

Zones of deuteric alteration (AZ: Figure 3c) are documented in a grain of placer Pt-Fe alloy of isoferroplatinum type $\left[\left(\mathrm{Pt}_{2.47} \mathrm{Rh}_{0.25} \mathrm{Pd}_{0.09}\right)_{\Sigma 2.8}\left(\mathrm{Fe}_{0.99} \mathrm{Cu}_{0.15} \mathrm{Ni}_{0.05}\right)_{\Sigma 1.2}\right]$. They occur near the grain margin, but are separated from it by the rim of S-bearing sperrylite $\left[\left(\mathrm{Pt}_{0.98} \mathrm{Rh}_{0.01}\right)_{\Sigma 0.99}\left(\mathrm{As}_{1.87} \mathrm{~S}_{0.12} \mathrm{Te}_{0.02}\right)_{\Sigma 2.01}\right]$. The matrix of the $\mathrm{Pt}-\mathrm{Fe}$ alloy grain consists of abundant lamellae, oriented crystallographically, of Ru-dominant alloy [ $\left.\mathrm{Ru}_{68.3} \mathrm{Ir}_{12.0} \mathrm{Os}_{7.2} \mathrm{Rh}_{6.9} \mathrm{Pt}_{5.7}\right]$.

In the altered zones, the late mineral assemblage is represented by bowieite rich in $\mathrm{Cu}(\# 5$, Table 4$)$, $\left[\left(\mathrm{Rh}_{0.70} \mathrm{Pt}_{0.65} \mathrm{Cu}_{0.61} \mathrm{Ru}_{0.05}\right)_{\Sigma 2.01}\left(\mathrm{~S}_{2.83} \mathrm{As}_{0.16}\right)_{\Sigma 2.99}\right]$, cooperite $\left[\left(\mathrm{Pt}_{0.88} \mathrm{Rh}_{0.04}\right)_{\Sigma 0.92} \mathrm{~S}_{1.08}\right]$ and, interestingly, a seleniferous variety of sperrylite (Figure 5b) that contains $\mathrm{Pt}$ 36.99, Rh 16.07, As 33.79, Se 11.01, $\mathrm{S} 3.5$, total $101.4 \mathrm{wt} \%$. The stoichiometric formula, $\left(\mathrm{Pt}_{0.54} \mathrm{Rh}_{0.45}\right)_{\Sigma 0.99}\left(\mathrm{As}_{1.29} \mathrm{Se}_{0.40} \mathrm{~S}_{0.31}\right)_{\Sigma 2.00}$, points to an uncommon variety of seleniferous and rhodiferous sperrylite. Alternatively, though less likely, this phase may represent an unnamed species of arsenosulfoselenide: $(\mathrm{Pt}, \mathrm{Rh}) \mathrm{As}_{1+x}\left(\mathrm{Se}_{,} \mathrm{S}\right)_{1-x}$.

\subsection{Tolovkite (IrSbS)_Irarsite (IrAsS)_Hollingworthite (RhAsS) Solid Solutions}

Members of the tolovkite (IrSbS) - irarsite (IrAsS) - hollingworthite (RhAsS) solid solution form inclusions $(\leq 20 \mu \mathrm{m})$ enclosed within the $\mathrm{Pt}-\mathrm{Au}-\mathrm{Cu}$ alloy. The observed existence of $\mathrm{Sb}-\mathrm{for}-\mathrm{As}$ substitution is especially noteworthy (Figure 9, Table 5), as it was also documented in related PGM from the Svetlyi Bor complex (Svetloborskiy) of the Urals: $\left(\operatorname{Ir}_{0.91} \operatorname{Rh}_{0.08} \mathrm{Fe}_{0.02}\right)_{\Sigma 1.01}\left(\mathrm{As}_{0.59} \mathrm{Sb}_{0.38}\right)_{\Sigma 0.97} \mathrm{~S}_{1.02}$ and $\left(\mathrm{Ir}_{1.01} \mathrm{Rh}_{0.03} \mathrm{Fe}_{0.03}\right)_{\Sigma 1.07}\left(\mathrm{As}_{0.73} \mathrm{Sb}_{0.20}\right)_{\Sigma 0.93} \mathrm{~S}_{1.00}$ [16]. Tolovkite from its type locality, the alluvial placers of the Tolovka River zone associated with the Alpine-type Ust'-Belskiy complex, Magadanskaya oblast, Russia, is close to its end-member composition, IrSbS [17]. Another series of solid solution extends from IrSbS (tolovkite) toward its Rh counterpart, unnamed RhSbS [18]. Note that some compositions are Pt-rich (\#16, Table 5), thus suggesting that the platarsite component (PtAsS [19]) also is involved.

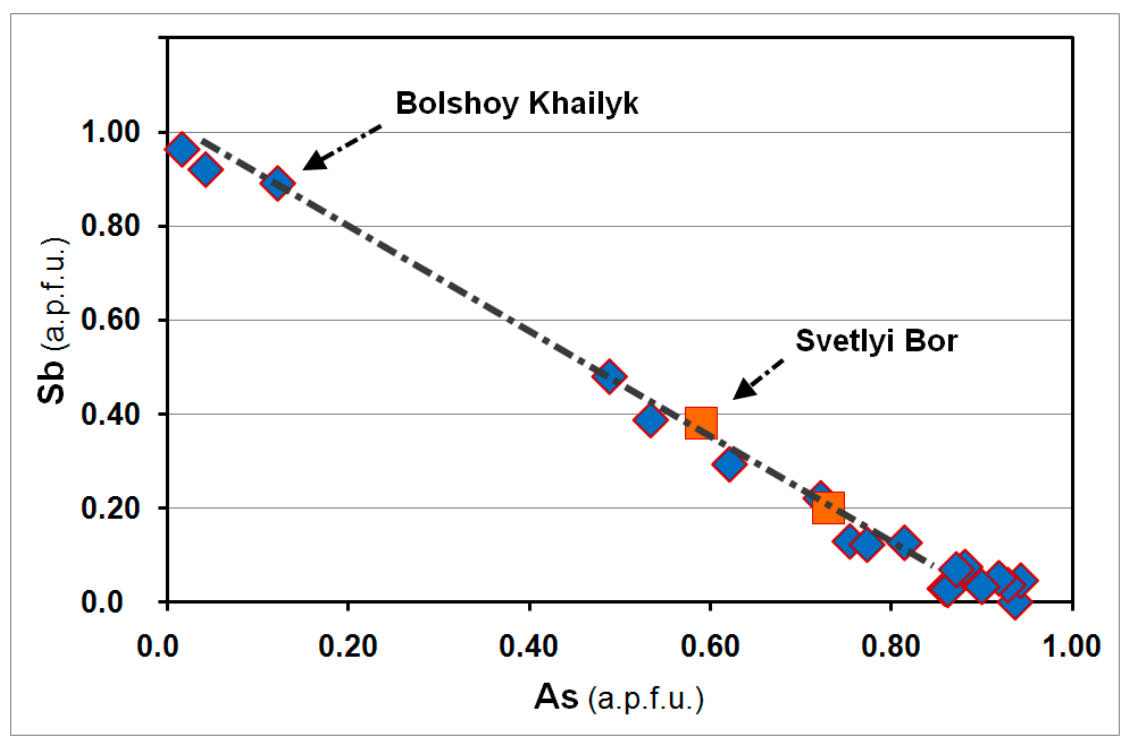

Figure 9. Compositional variations of phases of the tolovkite-irarsite solid solution from the Bolshoy Khailyk placer (this study) and the Svetlyi Bor (Svetloborskiy) complex, Urals, Russia [16]. 
Table 5. Compositions of the tolovkite-irarsite-hollingworthite solid solutions from the Bolshoy Khailyk deposit.

\begin{tabular}{|c|c|c|c|c|c|c|c|c|c|c|c|c|c|c|c|}
\hline$\#$ & Ir & $\mathbf{R h}$ & $\mathbf{R u}$ & Os & $\mathbf{P t}$ & $\mathrm{Au}$ & $\mathrm{Fe}$ & $\mathrm{Ni}$ & Co & $\mathrm{Cu}$ & $\mathrm{Sb}$ & As & $S$ & & Total \\
\hline 2 & 48.25 & 7.13 & bdl & 1.92 & bdl & bdl & 0.4 & 0.14 & bdl & 1.57 & 5.45 & 21.59 & 11.67 & & 98.12 \\
\hline 4 & 17.24 & 33.19 & bdl & bdl & bdl & bdl & bdl & bdl & bdl & 1.38 & 2.44 & 30.89 & 14.29 & & 99.43 \\
\hline 5 & 22.37 & 27.65 & bdl & bdl & bdl & bdl & bdl & bdl & bdl & 1.38 & 2.19 & 29.44 & 16.0 & & 99.03 \\
\hline 6 & 5.83 & 39.67 & bdl & bdl & 2.1 & 2.39 & bdl & bdl & bdl & 1.64 & 1.99 & 31.14 & 14.31 & & 99.07 \\
\hline 9 & 5.48 & 39.28 & bdl & bdl & 1.92 & bdl & bdl & bdl & bdl & 1.11 & 1.88 & 31.71 & 17.15 & & 98.53 \\
\hline 10 & 3.73 & 37.35 & bdl & bdl & 2.54 & 4.9 & bdl & bdl & bdl & 3.04 & 1.49 & 30.01 & 16.46 & & 99.52 \\
\hline 11 & bdl & 39.13 & bdl & bdl & 2.77 & 6.4 & bdl & bdl & bdl & 3.92 & 1.54 & 30.3 & 16.07 & & 100.13 \\
\hline 12 & 57.83 & bdl & 0.23 & 5.72 & bdl & bdl & bdl & bdl & bdl & bdl & 8.61 & 17.31 & 10.43 & & 100.13 \\
\hline 13 & 49.43 & bdl & 1.35 & bdl & bdl & bdl & bdl & bdl & bdl & bdl & 33.92 & 2.85 & 11.23 & & 98.78 \\
\hline 18 & 53.51 & bdl & bdl & bdl & bdl & bdl & bdl & 0.48 & bdl & bdl & 34.4 & 0.97 & 10.85 & & 100.21 \\
\hline 19 & 20.22 & 30.72 & bdl & bdl & 1.28 & bdl & bdl & bdl & 0.06 & 1.88 & 3.53 & 27.2 & 13.36 & & 98.25 \\
\hline 20 & 52.96 & 3.14 & bdl & 0.81 & 0.55 & bdl & 0.32 & 0.35 & 0.07 & 1.53 & 15.39 & 13.04 & 10.5 & & 98.66 \\
\hline 21 & 53.87 & 2.89 & bdl & 0.95 & 0.48 & bdl & 0.39 & 0.36 & 0.13 & 1.34 & 11.78 & 15.35 & 10.77 & & 98.31 \\
\hline \multicolumn{16}{|c|}{ Atomic proportions (per a total of 3 a.p.f.u.) } \\
\hline & Ir & Rh & $\mathbf{R u}$ & Os & $\mathbf{P t}$ & $\mathrm{Au}$ & $\mathrm{Fe}$ & $\mathrm{Ni}$ & Co & $\mathrm{Cu}$ & $\mathrm{Sb}$ & As & $S$ & $\Sigma \mathrm{Me}$ & $\mathrm{As}+\mathrm{Sb}$ \\
\hline 1 & 0.95 & 0.02 & 0 & 0 & 0 & 0 & 0.02 & 0 & 0 & 0 & 0.48 & 0.49 & 1.04 & 0.99 & 0.97 \\
\hline 2 & 0.71 & 0.20 & 0 & 0.03 & 0 & 0 & 0.02 & 0.01 & 0 & 0.07 & 0.13 & 0.81 & 1.03 & 1.03 & 0.94 \\
\hline 3 & 0.79 & 0.10 & 0 & 0 & 0 & 0 & 0.05 & 0 & 0 & 0.10 & 0 & 0.94 & 1.02 & 1.04 & 0.94 \\
\hline 11 & 0.00 & 0.81 & 0 & 0 & 0.03 & 0.07 & 0 & 0 & 0 & 0.13 & 0.03 & 0.86 & 1.07 & 1.04 & 0.89 \\
\hline 12 & 0.94 & 0 & 0.01 & 0.09 & 0 & 0 & 0 & 0 & 0 & 0 & 0.22 & 0.72 & 1.02 & 1.04 & 0.94 \\
\hline 13 & 0.82 & 0 & 0.04 & 0 & 0 & 0 & 0 & 0 & 0 & 0 & 0.89 & 0.12 & 1.12 & 0.87 & 1.01 \\
\hline 14 & 0.75 & 0.18 & 0 & 0 & 0 & 0 & 0 & 0 & 0 & 0 & 0.13 & 0.75 & 1.18 & 0.93 & 0.88 \\
\hline 15 & 0.76 & 0.17 & 0 & 0 & 0 & 0 & 0 & 0 & 0 & 0 & 0.12 & 0.77 & 1.18 & 0.92 & 0.90 \\
\hline 16 & 0.24 & 0.55 & 0 & 0 & 0.12 & 0 & 0 & 0 & 0 & 0 & 0.07 & 0.88 & 1.13 & 0.91 & 0.96 \\
\hline 17 & 0.93 & 0 & 0 & 0 & 0 & 0 & 0 & 0 & 0 & 0 & 0.96 & 0.02 & 1.09 & 0.93 & 0.98 \\
\hline 18 & 0.91 & 0 & 0 & 0 & 0 & 0 & 0 & 0.03 & 0 & 0 & 0.92 & 0.04 & 1.10 & 0.93 & 0.96 \\
\hline 19 & 0.25 & 0.72 & 0 & 0 & 0.02 & 0 & 0 & 0 & 0.002 & 0.07 & 0.07 & 0.87 & 1.00 & 1.06 & 0.94 \\
\hline 20 & 0.85 & 0.09 & 0 & 0.01 & 0.01 & 0 & 0.02 & 0.02 & 0.004 & 0.07 & 0.39 & 0.53 & 1.00 & 1.07 & 0.92 \\
\hline 21 & 0.85 & 0.09 & 0 & 0.02 & 0.01 & 0 & 0.02 & 0.02 & 0.007 & 0.06 & 0.29 & 0.62 & 1.02 & 1.07 & 0.91 \\
\hline
\end{tabular}

Note. Number 1-18 are results of SEM/EDS analyses, and \#19-21 are WDS analyses; "bdl" indicates that amounts of elements are below detection limits.

\subsection{Zoned Oxide of PGE-Fe}

Herein we describe an unusual grain of zoned oxide (or oxides), which consists of a core-like zone (marked with the letter C: Figure 6a), a rim-like zone $(\mathrm{R})$ and a veinlet $(\mathrm{V})$; these phases are rich in $\mathrm{Ru}$, and, to a lesser extent, in Os and Ir, with substantial Fe and minor V (Table 6). The following observations are noteworthy: (1) The compositions are generally consistent with a simplified formula $\mathrm{Ru}_{6} \mathrm{Fe}^{3+}{ }_{2} \mathrm{O}_{15}$, in which the atomic Me:O ratio is close to 1:2; this grain could have arisen by desulfurization and oxidation of laurite (zoned), in which the Me:S proportion also is 1:2. If so, Fe and V were introduced externally via the oxidizing fluid. (2) Compositional variations (Table 6) indicate that levels of Os and Ir decreased with a relative increase in Fe and V from core to rim. (3) A further change is expressed inward from the rim, with a decrease in the total PGE with increase in contents of $\mathrm{Fe}$ and $\mathrm{V}$; the low total suggests that the veinlet phase likely contains some water or a 
hydroxyl component. (4) The cavity observed in the center (Figure 6a) could represent the channelway of the oxidizing fluid.

Table 6. Compositions of PGE-Fe oxide phases in a zoned inclusion hosted by an Os-Ir-(Ru) alloy grain from the Bolshoy Khailyk placer deposit.

\begin{tabular}{|c|c|c|c|c|c|c|c|}
\hline$\#$ & & $\mathrm{RuO}_{2}$ & $\mathrm{OsO}_{2}$ & $\mathrm{Ir}_{2} \mathrm{O}_{3}$ & $\mathrm{Fe}_{2} \mathrm{O}_{3}$ & $\mathrm{~V}_{2} \mathrm{O}_{5}$ & Total \\
\hline 1 & Core & 64.89 & 9.97 & 6.45 & 18.35 & 0.97 & 100.63 \\
\hline 2 & Rim & 65.95 & 4.61 & 4.42 & 19.82 & 1.27 & 96.07 \\
\hline 3 & Veinlet & 50.35 & bdl & 1.91 & 24.78 & 1.95 & 78.99 \\
\hline \multicolumn{8}{|c|}{ Atomic proportions (per 15 oxygen atoms p.f.u.) } \\
\hline \# & & $\mathbf{R u}$ & Os & Ir & $\mathrm{Fe}^{3+}$ & $\mathbf{V}$ & $\Sigma$ PGE \\
\hline 1 & & 4.94 & 0.45 & 0.30 & 2.33 & 0.11 & 5.7 \\
\hline 2 & & 5.06 & 0.21 & 0.21 & 2.53 & 0.14 & 5.5 \\
\hline 3 & & 4.40 & 0 & 0.10 & 3.61 & 0.25 & 4.5 \\
\hline
\end{tabular}

Note. Results of SEM/EDS analyses are quoted in weight \%; "bdl” stands for not detected.

In various settings worldwide, grains of PGE-based oxides typically display similar features, e.g., [20-23]. These compounds remain poorly understood; in most occurrences, they could well represent cryptic mixtures rather than be single phases. Note that no bonding likely exists between platinum and oxygen in a $\mathrm{Pt}$-Fe oxide grain studied by X-ray absorption spectroscopy [24]. The Pd-based oxide grains appear to be more diverse in their compositions than grains of Ru-Os-Ir-rich oxides. Indeed, the Pd-rich grains contain a variety of elements, e.g., Sb, Bi, Pb, and Tl [25-27], which could well reflect diverse precursor grains.

\subsection{Pt-Au-Cu Alloys and Unnamed $(\mathrm{Pt}, \mathrm{Pd})_{3} \mathrm{Cu}_{2} \mathrm{Sn}$}

Four groups of clustered or individual data-points of $\mathrm{Pt}-\mathrm{Au}-\mathrm{Cu}$ alloys are recognized at Bolshoy Khailyk (\#1 to 4 in Figure 10) (Table 7). Field \#1 pertains to the phase $\mathrm{PtAu}_{4} \mathrm{Cu}_{5}$ [or $\left.\mathrm{Cu}(\mathrm{Au}, \mathrm{Pt})\right]$, the main portion of this grain (Figure 7a). The atomic proportions observed coincide with those of related intermetallic compounds reported from the Tulameen complex, Canada [28], an alluvial deposit at Sotajarvi, Finland [29], cf. [30], from the River Zolotaya [5], and from the Kondyor complex of Russia [31]. Note that the $\mathrm{Pt}-\mathrm{Au}-\mathrm{Cu}$ phases reported from Kondyor form a series of compositions toward $\mathrm{CuAu}$, i.e., tetra-auricupride, first discovered in China [32]. Thus, the analyzed phase at Bolshoy Khailyk could represent a member in the solid-solution series of platiniferous tetra-auricupride, i.e., $\mathrm{Cu}(\mathrm{Au}, \mathrm{Pt})$.

The compositional field \#2 is clustered near the stoichiometry PtAuCu 2 (Figure 10). The composition \#3 plots near PtCu, i.e., hongshiite [33]. Note that the auriferous hongshiite (Figure 10) is fairly close in composition to the phase reported from an alluvial occurrence at the River Durance, France [30]. The composition \#4 plots close to $\mathrm{PtAu}$, which is known from synthesis in nanometer-sized particles [34]. Field \#5 likely reflects a subordinate extent of solid solution of $\mathrm{Au}$ in a Cu-bearing platinum alloy (Figure 10, Table 7). The likely trend of crystallization of the $\mathrm{Pt}-\mathrm{Au}-\mathrm{Cu}$ alloys is shown in Figure 10. In addition, inclusions of highly pure platinum (100.8 wt \% Pt; EMP data) were encountered in this grain of the $\mathrm{Pt}-\mathrm{Au}-\mathrm{Cu}$ alloy.

An unnamed stannide of $\mathrm{Pt}$ and $\mathrm{Cu}$ with a subordinate content of $\mathrm{Pd}$ occurs as small inclusions ( $\leq 10 \mu \mathrm{m}$ across) in the matrix of the $\mathrm{Pt}-\mathrm{Au}-\mathrm{Cu}$ alloy. Compositional data (\#11-13, Table 7) indicate a $(\mathrm{Pt}+\mathrm{Pd}+\mathrm{Cu}): \mathrm{Sn}$ proportion of 5:1, which points to an unnamed species of PGM. In the system $\mathrm{Pd}_{3} \mathrm{Sn}-\mathrm{Cu}_{3} \mathrm{Sn}$ [35], several ternary phases are known to form via solid-state transformations at low temperatures $\leq 550^{\circ} \mathrm{C}$, with a general increase in $\mathrm{Cu}$ with a drop in temperature in the system, e.g., $\mathrm{Pd}_{5} \mathrm{CuSn} \mathrm{n}_{2}$ [or $\left(\mathrm{Pd}_{2.5} \mathrm{Cu}_{0.5}\right)_{\Sigma 3.0} \mathrm{Sn}$ ], $\mathrm{Pd}_{9} \mathrm{Cu}_{3} \mathrm{Sn}_{4}\left[\mathrm{Pd}_{2.25} \mathrm{Cu}_{0.75}\right)_{\Sigma 3.0} \mathrm{Sn}$ ] and $\mathrm{Pd}_{2} \mathrm{CuSn}$, which are likely the synthetic equivalents of "stannopalladinite", taimyrite and cabriite [36], respectively. The Pt-for-Pd substitution is known in the taimyrite series, the Pt-dominant analogue of which is tatyanaite $[37,38]$. 


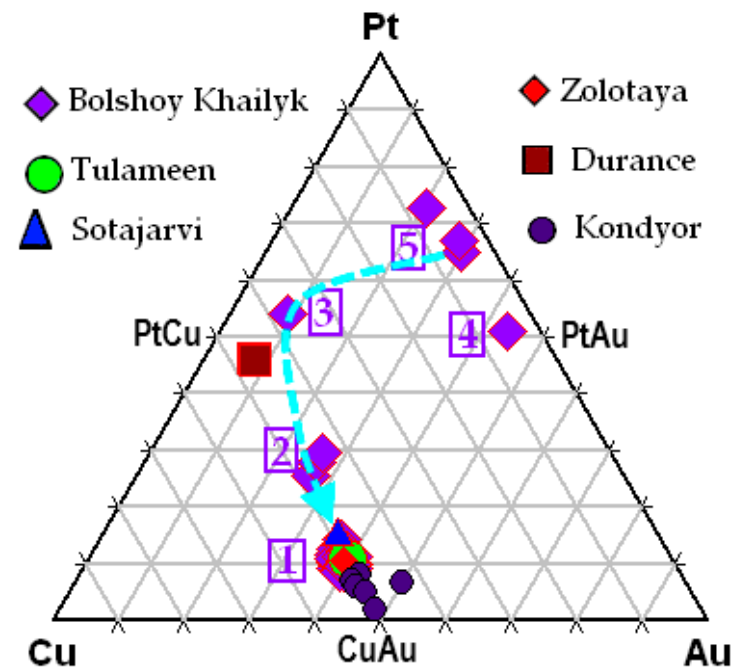

Figure 10. Compositions of alloys of $\mathrm{Cu}, \mathrm{Pt}$, and $\mathrm{Au}$ from the Bolshoy Khailyk placer (this study) on the diagram $\mathrm{Cu}-\mathrm{Pt}-\mathrm{Au}$ (at \%). For comparison, compositions of $\mathrm{Cu}-\mathrm{Pt}-\mathrm{Au}$ phases are plotted from the Zolotaya River placer, western Sayans [5], the Tulameen complex, Canada [28], the Sotajarvi area, Finland [29], the Durance River area, France [30], and the Kondyor complex, Russian Far East [31]. The numbers 1 to 5 , shown on this plot, pertain to compositional groups discussed in the text.

Table 7. Compositions of $\mathrm{Pt}-\mathrm{Au}-\mathrm{Cu}-(\mathrm{Sn})$ alloys from the Bolshoy Khailyk deposit.

\begin{tabular}{|c|c|c|c|c|c|c|c|c|c|}
\hline$\#$ & $\mathbf{P t}$ & $P d$ & $\mathrm{Fe}$ & $\mathbf{N i}$ & $\mathrm{Cu}$ & $\mathbf{A u}$ & $\mathrm{Sb}$ & Sn & Total \\
\hline 1 & 14.66 & bdl & bdl & bdl & 25.23 & 59.63 & bdl & bdl & 99.52 \\
\hline 2 & 16.03 & bdl & bdl & bdl & 24.1 & 60.5 & bdl & bdl & 100.63 \\
\hline 3 & 36.07 & bdl & bdl & bdl & 22.17 & 38.14 & 2.55 & 0.77 & 99.7 \\
\hline 4 & 38.41 & bdl & 1.74 & bdl & 20.39 & 36.34 & 0.91 & 3.13 & 100.92 \\
\hline 5 & 39.07 & bdl & 1.95 & bdl & 19.08 & 35.2 & 1.18 & 3.82 & 100.3 \\
\hline 6 & 65.36 & bdl & 1.05 & bdl & 14.7 & 10.85 & 6.45 & 1.26 & 99.67 \\
\hline 7 & 53.17 & bdl & bdl & bdl & 1.65 & 46.15 & bdl & bdl & 100.97 \\
\hline 8 & 75.55 & bdl & 0.45 & bdl & 2.26 & 21.61 & bdl & bdl & 99.87 \\
\hline 9 & 67.09 & bdl & bdl & bdl & 1.74 & 31.02 & bdl & bdl & 99.85 \\
\hline 10 & 68.51 & bdl & bdl & bdl & 1.49 & 29.22 & 0.46 & bdl & 99.68 \\
\hline 11 & 58.82 & 7.69 & 1.01 & 0.37 & 14.64 & 1.37 & bdl & 15.23 & 99.13 \\
\hline 12 & 59.63 & 7.37 & 0.99 & 0.36 & 14.78 & 1.39 & bdl & 15.77 & 100.29 \\
\hline 13 & 59.66 & 7.96 & 1.32 & 0.43 & 14.71 & 0.55 & bdl & 15.3 & 99.93 \\
\hline \multicolumn{10}{|c|}{ Atomic proportions } \\
\hline$\#$ & $\mathbf{P t}$ & Pd & $\mathrm{Fe}$ & $\mathbf{N i}$ & $\mathrm{Cu}$ & $\mathrm{Au}$ & $\mathrm{Sb}$ & Sn & \\
\hline 1 & 9.7 & 0 & 0 & 0 & 51.2 & 39.1 & 0 & 0 & \\
\hline 2 & 10.7 & 0 & 0 & 0 & 49.3 & 40.0 & 0 & 0 & \\
\hline 3 & 24.5 & 0 & 0 & 0 & 46.2 & 25.7 & 2.8 & 0.9 & \\
\hline 4 & 25.7 & 0 & 4.1 & 0 & 41.8 & 24.0 & 1.0 & 3.4 & \\
\hline 5 & 26.5 & 0 & 4.6 & 0 & 39.7 & 23.6 & 1.3 & 4.3 & \\
\hline 6 & 47.6 & 0 & 2.7 & 0 & 32.9 & 7.8 & 7.5 & 1.5 & \\
\hline 7 & 51.2 & 0 & 0 & 0 & 4.9 & 44.0 & 0 & 0 & \\
\hline 8 & 71.6 & 0 & 1.5 & 0 & 6.6 & 20.3 & 0 & 0 & \\
\hline 9 & 65.0 & 0 & 0 & 0 & 5.2 & 29.8 & 0 & 0 & \\
\hline 10 & 66.7 & 0 & 0 & 0 & 4.5 & 28.2 & 0.7 & 0 & \\
\hline 11 & 2.37 & 0.57 & 0.14 & 0.05 & 1.81 & 0.05 & 0 & 1.01 & \\
\hline 12 & 2.38 & 0.54 & 0.14 & 0.05 & 1.81 & 0.05 & 0 & 1.03 & \\
\hline 13 & 2.37 & 0.58 & 0.18 & 0.06 & 1.79 & 0.02 & 0 & 1.00 & \\
\hline
\end{tabular}

Note. Analyses \# 1-10 are compositions of $\mathrm{Pt}-\mathrm{Cu}-\mathrm{Au}$ alloy phases, which are listed in the order of increasing $\mathrm{Pt}$ content. Analyses \#1 and 2 correspond to $\mathrm{PtCu}_{5} \mathrm{Au}_{4}$ [or $\left.\mathrm{Cu}(\mathrm{Au}, \mathrm{Pt})\right]$. \#11-13 pertain to unnamed $(\mathrm{Pt}, \mathrm{Pd})_{3} \mathrm{Cu}{ }_{2} \mathrm{Sn}$. An.\#2 and \#11-13 are results of WDS analyses; \#1 and \#3-10 are results of SEM/EDS; "bdl" indicates that amounts of elements are below detection limits. The atomic proportions are expressed per a total of 100 at $\%$, except for \#11-13 recalculated on the basis of a total of 6 a.p.f.u. 


\subsection{Rh-Co-Rich Pentlandite}

It is known that pentlandite incorporates essential Rh or Co (e.g., [8,39-43]). In contrast to other occurrences, compositions of pentlandite at Bolshoy Khailyk display covariations of Co and Rh, both present in significant amounts in solid solution (Table 8). Thus, our results provide useful implications to establish a likely mechanism of the Rh incorporation. A total of 19 grains were analyzed, all of them subhedral to anhedral inclusions ( $\leq 20 \mu \mathrm{m}$ across) hosted by the Pt-Au-Cu alloy (Figure 7a,b). The pair Co-Fe reveals a strongly negative correlation, whereas the pair Co-Ni is uncorrelated (Figure 11a,b). Interestingly, contents of Co display a significant and sympathetic correlation with $\mathrm{Rh}$, a coefficient of correlation $\mathrm{R}$ of 0.8 (Figure 11c). The pair Fe-Rh is negatively correlated $(\mathrm{R}=-0.8)$. There are no definite correlations involving Ni with Rh or Fe (Figure 11e,f).

Table 8. Compositions of Co-Rh-bearing pentlandite from the Bolshoy Khailyk deposit.

\begin{tabular}{|c|c|c|c|c|c|c|c|c|c|}
\hline & $\mathrm{Fe}$ & $\mathrm{Ni}$ & Co & $\mathrm{Cu}$ & $\mathbf{R h}$ & Ir & $\mathbf{P t}$ & $S$ & Total \\
\hline 1 & 13.55 & 35.60 & 11.59 & 0.05 & 4.54 & 0.74 & $\mathrm{bdl}$ & 31.38 & 97.45 \\
\hline 2 & 13.38 & 35.68 & 11.61 & 0.43 & 4.92 & 0.76 & bdl & 31.46 & 98.24 \\
\hline 3 & 13.46 & 35.94 & 11.44 & 0.43 & 4.79 & 0.84 & bdl & 31.40 & 98.30 \\
\hline 4 & 20.71 & 36.48 & 5.57 & 0.63 & 1.23 & 0.66 & bdl & 31.85 & 97.13 \\
\hline 5 & 20.72 & 36.59 & 5.70 & 0.48 & 1.34 & 0.61 & bdl & 31.95 & 97.39 \\
\hline 6 & 21.28 & 39.81 & 3.57 & 0.44 & 0.10 & bdl & 0.34 & 31.61 & 97.15 \\
\hline 7 & 15.88 & 34.02 & 13.34 & 0.36 & 2.6 & 0.33 & bdl & 31.67 & 98.20 \\
\hline 8 & 15.91 & 34.15 & 13.27 & 0.29 & 2.68 & 0.31 & bdl & 31.68 & 98.29 \\
\hline 9 & 15.71 & 37.54 & 10.31 & 0.49 & 1.24 & 1.12 & bdl & 31.78 & 98.19 \\
\hline 10 & 15.87 & 33.67 & 13.32 & 0.31 & 2.88 & 0.40 & bdl & 31.64 & 98.09 \\
\hline 11 & 22.08 & 30.36 & 2.56 & 2.33 & bdl & bdl & 11.43 & 31.64 & 100.40 \\
\hline 12 & 17.56 & 33.44 & 11.58 & bdl & 3.27 & bdl & bdl & 35.01 & 100.86 \\
\hline 13 & 17.68 & 32.90 & 11.63 & bdl & 3.34 & bdl & bdl & 34.49 & 100.04 \\
\hline 14 & 17.16 & 34.29 & 11.8 & bdl & 1.5 & bdl & bdl & 35.54 & 100.29 \\
\hline 15 & 19.27 & 35.73 & 8.74 & bdl & 1.56 & bdl & bdl & 35.57 & 100.87 \\
\hline 16 & 23.97 & 30.32 & 1.44 & 1.52 & bdl & bdl & 10.25 & 31.99 & 99.49 \\
\hline 17 & 21.62 & 36.12 & 5.89 & bdl & 1.12 & bdl & bdl & 35.17 & 99.92 \\
\hline 18 & 23.75 & 37.36 & 3.33 & bdl & bdl & bdl & bdl & 36.01 & 100.45 \\
\hline 19 & 17.68 & 39.53 & 8.82 & bdl & bdl & bdl & bdl & 34.07 & 100.10 \\
\hline \multicolumn{10}{|c|}{ Atomic proportions (per a total of 17 a.p.f.u.) } \\
\hline & $\mathrm{Fe}$ & $\mathrm{Ni}$ & Co & $\mathrm{Cu}$ & $\mathbf{R h}$ & Ir & $\mathbf{P t}$ & $\Sigma \mathrm{Me}$ & $S$ \\
\hline 1 & 1.99 & 4.97 & 1.61 & 0.01 & 0.36 & 0.03 & 0 & 8.97 & 8.03 \\
\hline 2 & 1.95 & 4.96 & 1.61 & 0.06 & 0.39 & 0.03 & 0 & 9.00 & 8.00 \\
\hline 3 & 1.97 & 4.99 & 1.58 & 0.06 & 0.38 & 0.04 & 0 & 9.01 & 7.99 \\
\hline 4 & 2.99 & 5.02 & 0.76 & 0.08 & 0.10 & 0.03 & 0 & 8.98 & 8.02 \\
\hline 5 & 2.99 & 5.02 & 0.78 & 0.06 & 0.10 & 0.03 & 0 & 8.98 & 8.02 \\
\hline 6 & 3.06 & 5.45 & 0.49 & 0.06 & 0.01 & 0 & 0.01 & 9.08 & 7.92 \\
\hline 7 & 2.29 & 4.67 & 1.82 & 0.05 & 0.20 & 0.01 & 0 & 9.04 & 7.96 \\
\hline 8 & 2.29 & 4.68 & 1.81 & 0.04 & 0.21 & 0.01 & 0 & 9.05 & 7.95 \\
\hline 9 & 2.26 & 5.15 & 1.41 & 0.06 & 0.10 & 0.05 & 0 & 9.02 & 7.98 \\
\hline 10 & 2.29 & 4.63 & 1.82 & 0.04 & 0.23 & 0.02 & 0 & 9.03 & 7.97 \\
\hline 11 & 3.30 & 4.31 & 0.36 & 0.31 & 0 & 0 & 0.49 & 8.77 & 8.23 \\
\hline 12 & 2.42 & 4.39 & 1.52 & 0 & 0.25 & 0 & 0 & 8.58 & 8.42 \\
\hline 13 & 2.47 & 4.37 & 1.54 & 0 & 0.25 & 0 & 0 & 8.62 & 8.38 \\
\hline 14 & 2.36 & 4.48 & 1.54 & 0 & 0.11 & 0 & 0 & 8.49 & 8.51 \\
\hline 15 & 2.63 & 4.65 & 1.13 & 0 & 0.12 & 0 & 0 & 8.53 & 8.47 \\
\hline 16 & 3.57 & 4.30 & 0.20 & 0.20 & 0 & 0 & 0.44 & 8.70 & 8.30 \\
\hline 17 & 2.98 & 4.73 & 0.77 & 0 & 0.08 & 0 & 0 & 8.56 & 8.44 \\
\hline 18 & 3.23 & 4.83 & 0.43 & 0 & 0 & 0 & 0 & 8.48 & 8.52 \\
\hline 19 & 2.44 & 5.20 & 1.16 & 0 & 0 & 0 & 0 & 8.80 & 8.20 \\
\hline
\end{tabular}

Note. Number 1-10 are results of WDS analyses. \#11-19 are SEM/EDS analyses; “bdl” indicates that amounts of elements are below detection limits. 

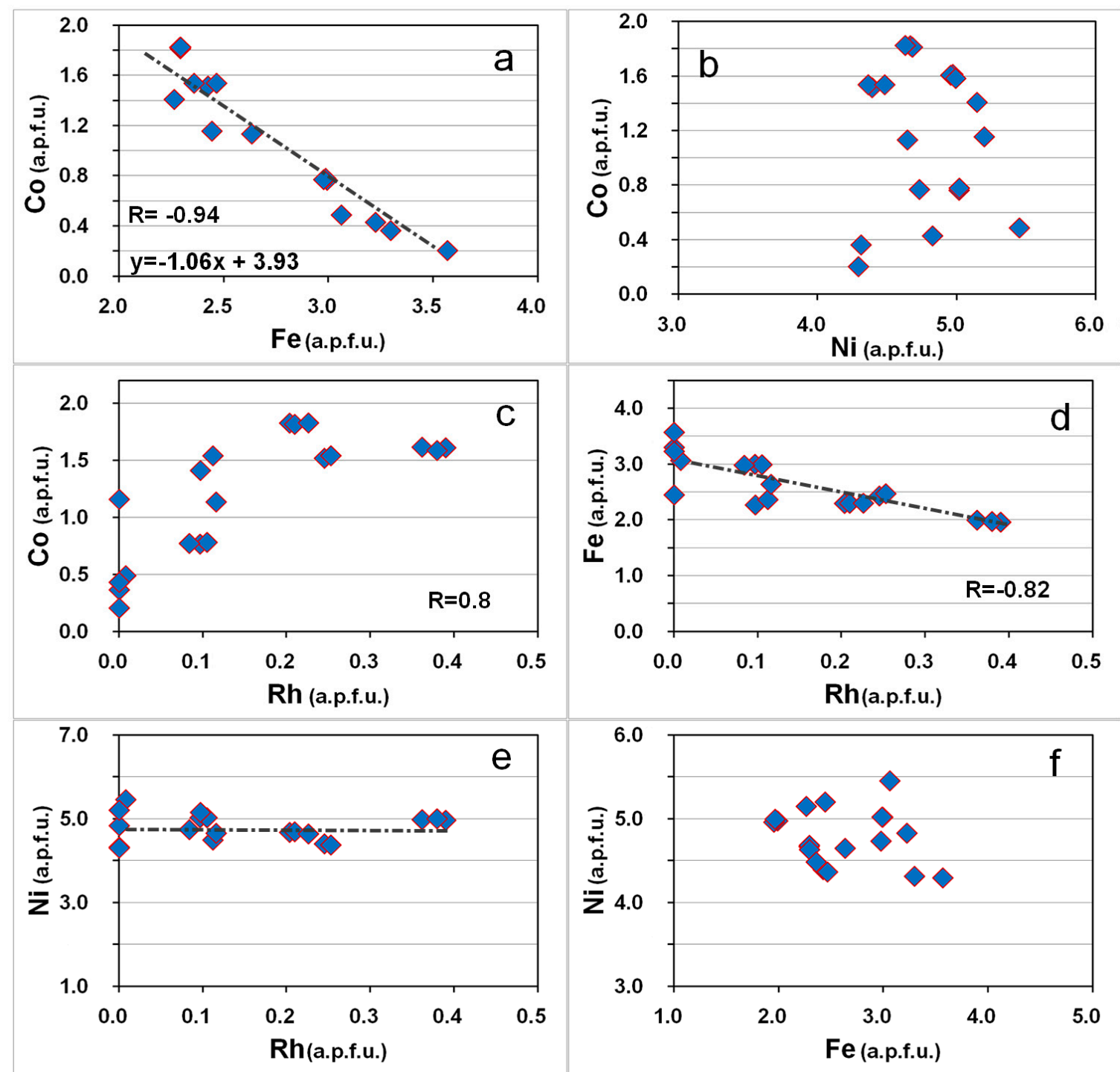

Figure 11. Variations and correlations observed in compositions of Rh-Co-rich pentlandite from the Bolshoy Khailyk placer in terms of binary plots Co vs. Fe (a), Co vs. Ni (b), Co vs. Rh (c), Fe vs. Rh (d), Ni vs. Rh (e), and Ni vs. Fe (f), with values expressed in values of atoms per formula unit, a.p.f.u., calculated for a total of 17 a.p.f.u. Values of the correlation coefficient $\mathrm{R}$ are shown, along with an equation of linear regression in (a).

\subsection{Micrometer-Sized Inclusions in Grains of PGE Alloys}

In general, placer grains of Os-Ir-Ru alloys contain inclusions more commonly than the Pt-Fe alloys. The analyzed inclusions of diopside (Table 9) are highly magnesian [Wo $\mathrm{Wr}_{48.3-48.6} \mathrm{En}_{48.4-48.5} \mathrm{Fs}_{2.6} \mathrm{Ae}_{0.4-0.7} ; \mathrm{Mg} \#$ 96.9-97.9]. Inclusions of chromian spinel correspond to magnesiochromite; these are also highly magnesian, with values of Mg\# up to 71. In addition, the chromian spinel displays unusually high values of Cr\# (77-83.5: Table 9). Some grains (Figure 4d) possibly represent broken fragments of subhedral spinel from the lode rock. 
Table 9. Compositions of inclusions of silicate minerals and chromian spinel hosted by placer grains of PGM from the Bolshoy Khailyk placer deposit.

\begin{tabular}{|c|c|c|c|c|c|c|c|c|c|c|c|c|c|c|}
\hline$\#$ & & $\mathrm{SiO}_{2}$ & $\mathrm{TiO}_{2}$ & $\mathrm{Al}_{2} \mathrm{O}_{3}$ & $\mathrm{Cr}_{2} \mathrm{O}_{3}$ & $\mathrm{FeO}$ (tot) & $\mathrm{FeO}$ (calc.) & $\mathrm{Fe}_{2} \mathrm{O}_{3}$ (calc.) & $\mathrm{MnO}$ & $\mathrm{MgO}$ & $\mathrm{CaO}$ & $\mathrm{Na}_{2} \mathrm{O}$ & $\mathrm{K}_{2} \mathrm{O}$ & Total \\
\hline 2 & & 53.4 & 0.02 & 1.74 & 0.81 & 1.62 & 0.07 & 1.72 & 0.05 & 17.7 & 24.7 & 0.12 & bdl & 100.16 \\
\hline 3 & Amp & 53.9 & 0.03 & 3.62 & 0.12 & 9.05 & bdl & bdl & 0.18 & 16.8 & 11.5 & 0.46 & 0.05 & 95.71 \\
\hline 4 & & 49.5 & 0.05 & 8.43 & 0.52 & 9.67 & bdl & bdl & 0.09 & 15.1 & 10.8 & 0.54 & 0.29 & 94.99 \\
\hline 5 & & 49.2 & 0.09 & 8.85 & 0.36 & 8.43 & 8.17 & 0.30 & 0.12 & 16.6 & 11.0 & 0.55 & 0.03 & 95.23 \\
\hline 6 & & 49.7 & 0.08 & 9.85 & 0.09 & 8.83 & bdl & bdl & 0.13 & 16.5 & 10.2 & 0.61 & 0.04 & 96.03 \\
\hline 7 & & 51.1 & 0.04 & 7.67 & 0.11 & 8.92 & bdl & bdl & 0.05 & 17.9 & 9.3 & 0.82 & 0.18 & 96.09 \\
\hline 9 & & 51.7 & bdl & 8.5 & 0.55 & 9.83 & bdl & bdl & bdl & 15.6 & 12.3 & bdl & 0.31 & 98.79 \\
\hline 10 & & 51.3 & bdl & 8.2 & 0.58 & 10.7 & bdl & bdl & bdl & 16.4 & 9.7 & bdl & 0.28 & 97.16 \\
\hline 11 & & 51.8 & bdl & 11.5 & 0.20 & 5.44 & bdl & bdl & bdl & 18.3 & 11.8 & 0.9 & bdl & 99.94 \\
\hline 12 & & 49.0 & bdl & 12.2 & bdl & 4.0 & 2.34 & 1.84 & bdl & 17.3 & 13.2 & bdl & bdl & 95.7 \\
\hline 13 & & 49.4 & bdl & 10.9 & 0.41 & 4.32 & 3.00 & 1.46 & bdl & 17.8 & 12.4 & bdl & bdl & 95.23 \\
\hline 14 & & 54.3 & bdl & 6.63 & bdl & 8.46 & 7.57 & 0.99 & bdl & 18.5 & 12.2 & bdl & bdl & 100.09 \\
\hline 19 & & bdl & 0.08 & 7.64 & 57.5 & 19.4 & 17.91 & 1.66 & 1.27 & 8.0 & bdl & bdl & bdl & 94.06 \\
\hline 20 & & bdl & 0.07 & 7.74 & 57.8 & 19.3 & 18.08 & 1.36 & 1.16 & 8.0 & bdl & bdl & bdl & 94.21 \\
\hline 21 & & bdl & 0.10 & 7.61 & 57.4 & 19.4 & 17.20 & 2.44 & 0.52 & 9.0 & bdl & bdl & bdl & 94.27 \\
\hline 22 & & bdl & 0.09 & 8.2 & 56.6 & 18.4 & 15.18 & 3.58 & 0.40 & 10.5 & bdl & bdl & bdl & 94.55 \\
\hline 23 & & bdl & bdl & 10.5 & 52.1 & 22.9 & 20.22 & 2.98 & 0.49 & 7.1 & bdl & bdl & bdl & 93.39 \\
\hline 24 & & bdl & bdl & 8.3 & 61.4 & 17.9 & 15.67 & 2.48 & bdl & 11.4 & bdl & bdl & bdl & 99.25 \\
\hline 25 & & bdl & bdl & 8.5 & 61.3 & 17.7 & 15.78 & 2.13 & bdl & 11.3 & bdl & bdl & bdl & 99.01 \\
\hline \multicolumn{15}{|c|}{ Atomic proportions } \\
\hline & $\mathrm{Si}$ & $\mathrm{Mg}$ & $\mathrm{Fe}^{2+}$ & $\mathrm{Ca}$ & Mn & $\mathrm{Na}$ & $\mathrm{K}$ & $\mathrm{Cr}$ & Al & $\mathrm{Fe}^{3+}$ & Ti & Mg\# & Cr\# & $\mathrm{Fe}^{3+} \#$ \\
\hline 1 & 1.94 & 0.95 & 0.02 & 0.95 & $<0.01$ & 0.01 & 0 & 0.02 & 0.08 & 0.03 & $<0.01$ & 96.9 & - & - \\
\hline 2 & 1.93 & 0.95 & $<0.01$ & 0.96 & $<0.01$ & 0.01 & 0 & 0.02 & 0.07 & 0.05 & $<0.01$ & 97.9 & - & - \\
\hline 11 & 7.03 & 3.7 & 0.62 & 1.72 & 0 & 0.24 & 0 & 0.02 & 1.84 & 0 & 0 & 85.6 & - & - \\
\hline 12 & 6.89 & 3.63 & 0.28 & 1.99 & 0 & 0 & 0 & 0 & 2.02 & 0.2 & 0 & 92.8 & - & - \\
\hline 13 & 6.99 & 3.76 & 0.36 & 1.88 & 0 & 0 & 0 & 0.05 & 1.82 & 0.16 & 0 & 91.3 & - & - \\
\hline 14 & 7.42 & 3.77 & 0.86 & 1.79 & 0 & 0 & 0 & 0 & 1.07 & 0.1 & 0 & 81.4 & - & - \\
\hline 15 & 2.09 & 2.62 & 0.18 & 0 & 0.01 & 0 & 0 & 0 & 0 & 0 & 0 & 93 & - & - \\
\hline 16 & 2.09 & 2.63 & 0.19 & 0 & 0.01 & 0 & 0 & 0 & 0 & 0 & 0 & 92.9 & - & - \\
\hline 17 & 0 & 0.7 & 0.29 & 0 & 0.01 & 0 & 0 & 1.56 & 0.32 & 0.12 & 0.003 & 69.8 & 83.1 & 5.8 \\
\hline 18 & 0 & 0.71 & 0.29 & 0 & 0.01 & 0 & 0 & 1.56 & 0.31 & 0.12 & 0.002 & 70.6 & 83.5 & 6.2 \\
\hline 19 & 0 & 0.43 & 0.54 & 0 & 0.04 & 0 & 0 & 1.63 & 0.32 & 0.04 & 0.002 & 42.6 & 83.5 & 2.2 \\
\hline 20 & 0 & 0.43 & 0.54 & 0 & 0.04 & 0 & 0 & 1.63 & 0.33 & 0.04 & 0.002 & 42.6 & 83.4 & 1.8 \\
\hline 21 & 0 & 0.48 & 0.51 & 0 & 0.02 & 0 & 0 & 1.61 & 0.32 & 0.07 & 0.003 & 47.5 & 83.5 & 3.3 \\
\hline 22 & 0 & 0.55 & 0.44 & 0 & 0.01 & 0 & 0 & 1.56 & 0.34 & 0.09 & 0.002 & 54.6 & 82.2 & 4.7 \\
\hline 23 & 0 & 0.38 & 0.61 & 0 & 0.01 & 0 & 0 & 1.48 & 0.44 & 0.08 & 0 & 37.9 & 76.9 & 4 \\
\hline 24 & 0 & 0.56 & 0.44 & 0 & 0 & 0 & 0 & 1.61 & 0.33 & 0.06 & 0 & 56.5 & 83.2 & 3.1 \\
\hline 25 & 0 & 0.56 & 0.44 & 0 & 0 & 0 & 0 & 1.61 & 0.33 & 0.05 & 0 & 56.1 & 82.9 & 2.7 \\
\hline
\end{tabular}

Note. These results of WDS analyses are expressed in weight\%; "bdl" indicates that amounts of elements are below detection limits. The label Cpx is clinopyroxene (diopside), Amp is amphibole, Srp is serpentine, and Chr is chromian spinel (chromite-magnesiochromite series). An.\#3-14 pertain to amphiboles. An.\#3 corresponds to actinolite, $\# 4-6,8,9,11-14$ to magnesio-hornblende, and \#7, 10 are barroisite. $\mathrm{FeO}$ (tot) is all $\mathrm{Fe}$ as $\mathrm{FeO}$. $\mathrm{FeO}$ (calc.) and $\mathrm{Fe}_{2} \mathrm{O}_{3}$ (calc.) are values calculated on the basis of stoichiometry and charge balance. The atomic proportions are based on $\mathrm{O}=6$ a.p.f.u. for $\mathrm{Cpx}, \mathrm{O}=23$ for Amp, $\mathrm{O}=7$ for Srp, and $\mathrm{O}=4$ for chromian spinel. The index $\mathrm{Mg} \#$ is $100 \mathrm{Mg} /\left(\mathrm{Mg}+\mathrm{Fe}^{2+}+\mathrm{Mn}\right) ; \mathrm{Cr} \#$ is $100 \mathrm{Cr} /(\mathrm{Cr}+\mathrm{Al}) ;$ and $\mathrm{Fe}^{3+} \#$ is $100 \mathrm{Fe}^{3+} /\left(\mathrm{Fe}^{3+}+\mathrm{Cr}+\mathrm{Al}\right)$.

The amphibole inclusions are relatively abundant; they correspond to actinolite, magnesio-hornblende, and barroisite. Some of the inclusions of amphibole have Mg-rich compositions, with values of Mg\# up to 93 (Table 9).

Some other inclusions crystallized from much more fractionated silicate melts. Among these are grains of nearly end-member albite $\left(\mathrm{Ab}_{>90}\right)$, hosted by a placer grain of Ru-dominant alloy 
$\left[\mathrm{Ru}_{56.1} \mathrm{Os}_{39.8} \mathrm{Ir}_{4.1}\right]$, and inclusions of quartz (up to $\sim 50 \mu \mathrm{m}$ ) hosted by a grain of a ternary alloy, $\mathrm{Ir}_{35.5} \mathrm{Os}_{32.6} \mathrm{Ru}_{31.9}$. Euhedral grains of quartz were noted in inclusions hosted by Ir-dominant alloy from a placer deposit in British Columbia, Canada [44]. Plagioclase inclusions [ $\mathrm{Ab}_{58} \mathrm{An}_{42} \mathrm{Or}_{0.6}$ ] were found in the Pt-Au-Cu alloy grain at Bolshoy Khailyk. Serpentine (Table 9) and calcite are locally present in inclusions. A micrometric inclusion of grossular(?), with $\sim 0.5 \% \mathrm{Cr}_{2} \mathrm{O}_{3}$ and $3.7 \% \mathrm{MgO}$, displays a notable departure from normal stoichiometry, and likely is not single-phase. Compositions of five inclusions of magnetite (Figure $7 \mathrm{~b}$; WDS data) are relatively pure, with up to $0.52 \% \mathrm{MgO}, 0.30 \% \mathrm{Cr}_{2} \mathrm{O}_{3}$, and $0.31 \mathrm{wt} \% \mathrm{MnO}$.

\section{Discussion}

\subsection{Provenance and Genetic Implications}

We have pointed out the close association of the placer deposit with abundant bodies of ophiolitic serpentinite (Figure 1). In addition, we document a high extent of Ru-enrichment in the association of PGM at Bolshoy Khailyk. These characteristics clearly point to an ophiolitic source of the placer PGM, which is presumably related to the Aktovrakskiy complex, belonging to the Kurtushibinskiy belt of the western Sayans. The faceted morphology of the placer grains (Figure $3 \mathrm{~b}, \mathrm{~d}, \mathrm{f}$ ) is consistent with a short distance of transport from the source rocks. The Aktovrakskiy complex was previously inferred to be the primary source for the associated PGM placers at the Zolotaya River, western Sayans [5]. We thus contend that this suite and related complexes of potentially mineralized ophiolites are the targeted PGM-producing source in other areas of the Altai-Sayan folded region.

We document the very high extents of Mg-enrichment in the inclusions of clinopyroxene (Mg\# 96.9-97.9) and chromian spinel (Mg\# 71) hosted by PGE alloys. In addition, serpentine is present, indicating the former presence of olivine in the system. Some of the amphibole inclusions also are highly magnesian $(\mathrm{Mg \#}>90)$, consistent with their crystallization in a primitive ultramafic rock. Therefore, the bulk of the investigated Os-Ir-Ru and Pt-Fe alloy minerals (with abundant exsolution of a Ru-dominant alloy) seem to have crystallized in a high-Mg chromitite or in a dunitic rock rich in magnesiochromite, with a subordinate role of pyroxenitic rocks inferred on the basis of the presence of quartz inclusions hosted by the PGE alloy.

We infer that subhedral grains of Os-Ir-Ru alloys crystallized first among the PGM and after the associated Mg-rich magnesiochromite and olivine, followed by subhedral grains of the isoferroplatinum-type alloy (Figure 3b,f); lamellar phases of Ru-dominant alloy (Figures 3b and 5a) formed largely by exsolution from the matrix phase upon cooling. They reflect a general enrichment in Ru existing in the lode ophiolite, and imply accumulation of levels of Ru during progressive crystallization of the Pt-Fe alloy. The presence of inclusions of amphiboles with lower values of Mg\# (73-78; Table 9), and, especially, of Ab-rich plagioclase and quartz, imply that high degrees of fractionation were locally achieved in the ore-forming system.

The inferred incompatible behavior of minor constituents like S, As, Sb, Se, Sn, Au and base-metals $(\mathrm{Cu}, \mathrm{Ni}, \mathrm{Co}, \mathrm{Fe})$ was accompanied during the crystallization of Os-Ir-Ru-Pt alloys by a gradual buildup in the fugacity of $S_{2}$ and $A s_{2}$. Consequently, a variety of sulfide, arsenide, antimonide, and intermetallic phases crystallized at this point, at a lower temperature, possibly at the expense of droplets of residual melt as micrometric inclusions, or as phases coexisting in altered zones near the rims. These implications are consistent with observations made at other placer deposits e.g., [8,18], and references therein. In addition, the porous texture of the Fe-enriched rims (Figure 3e) may reflect the abundance of volatile species; they are similar to rims developed in grains of $\mathrm{Ir}-\mathrm{Ru}-\mathrm{O}$ alloys from a placer associated with the Trinity ophiolite complex in California $[45,46]$.

The zones of metasomatic modification (Figures $3 c$ and $5 b$ ) formed, presumably, as a consequence of (1) the expected buildup in levels of $f S_{2}$ and $f \mathrm{As}_{2}$, (2) an accumulation of levels of incompatible constituents, such as $\mathrm{Cu}$ and $\mathrm{Se}$, in the isolated portions at the margins during the crystallization of the $\mathrm{Pt}-\mathrm{Fe}$ alloy (the external rim of sperrylite is developed around the grain), and (3) the late deposition of 
the S-As-Se-bearing assemblage as a result of subsolidus reactions and deuteric alteration of the early formed Pt-Fe alloy phase.

\subsection{PGE-Ni-Fe-Cu Alloy, PGE-Fe Oxide and Potential Mineral-Forming Reactions}

Corresponding redox reactions likely proceeded at a low temperature and led to the deposition of the alloys of $(\mathrm{Pt}, \mathrm{Ir})(\mathrm{Ni}, \mathrm{Fe}, \mathrm{Cu})_{3-x}$ type and PGE oxide (Figure 6a-c). These alloys occur as veinlets developed in porous and fractured zones at margins of placer grains. We suggest that they crystallized under reducing conditions at the expense of pre-existing pentlandite via a schematic reaction: $\left[(\mathrm{Ni}, \mathrm{Fe})_{9} \mathrm{~S}_{8}+3 \mathrm{Pt}+8 \mathrm{H}_{2} \rightarrow 3 \mathrm{Pt}(\mathrm{Ni}, \mathrm{Fe})_{3}+8 \mathrm{H}_{2} \mathrm{~S}\right]$. The Pt component was likely introduced and remobilized by a volatile phase from the associated PGE alloy. The other reactant, hydrogen, was likely a product of the serpentinization of olivine upon oxidation of $\mathrm{Fe}^{2+}$ in primary silicates to $\mathrm{Fe}^{3+}$ by a reaction involving $\mathrm{H}_{2} \mathrm{O}$ ([47], and references therein).

The zoned grain of PGE-Fe oxide could form by combined oxidation and desulfurization of zoned grains of Ru-Os disulfide of the laurite-erlichmanite series. As noted, the observed zonal texture (Figure 6a) is likely a reflection of primary compositional zoning with respect to Ru-Os-(Ir), which is common in grains of laurite-erlichmanite worldwide. The likely schematic reaction at Bolshoy Khailyk is: $\left[6 \mathrm{RuS}_{2}+\mathrm{Fe}_{2} \mathrm{O}_{3}+18 \mathrm{O}_{2} \rightarrow \mathrm{Ru}_{6} \mathrm{Fe}_{2} \mathrm{O}_{15}+12 \mathrm{SO}_{2}\right]$, which involves a hematite component introduced by an oxidizing fluid phase.

\subsection{Origin of $A u-(C u-P t)$-Rich Mineralization}

The occurrence of $\mathrm{Au}-(\mathrm{Cu}-\mathrm{Pt})$ alloys, i.e., $\mathrm{PtAu}_{4} \mathrm{Cu}_{5}, \mathrm{PtAuCu}_{2}, \mathrm{Pt}(\mathrm{Cu}, \mathrm{Au}), \mathrm{PtAu}$, and $\mathrm{Au}$-bearing platinum alloy (Figure 10) appears to be related genetically with the Os-Ir-Ru-Pt mineralization at Bolshoy Khailyk. Thus, the inferred ophiolitic system was likely able to produce locally a high extent of Au-enrichment as a result of geochemical evolution and deposition from a fractionated $\mathrm{Au}-\mathrm{Cu}$-rich melt, which likely gained high levels of incompatible $\mathrm{Cu}+\mathrm{Au}$ with subordinate $\mathrm{Pt}$ in a remaining volume during the bulk crystallization of Os-Ir-Ru alloy phases, after the preceding crystallization of chromian spinel (magnesiochromite) and olivine. The latter are presumably the main minerals in the inferred lode rocks (chromitite or magnesiochromite-rich dunite). As noted, PGE alloy grains hosting the quartz inclusions imply a pyroxenitic rock, which could be relevant to some other PGM grains containing inclusions of Ab-rich plagioclase and Fe-rich amphibole.

This suggestion is corroborated by the occurrence of an elevated Au content (up to $7.5 \mathrm{wt} \%$ ) in the Fe-bearing Ir-Ru-Os alloy phases found associated with the Trinity ophiolite complex, California [46]. In addition, an $\mathrm{Au}-\mathrm{Ag}$ alloy, ranging up to almost pure gold $\left(\mathrm{Au}_{99}\right)$, precipitated pseudomorphously by a subsolidus reaction between a fluid phase or a residual $\mathrm{Au}-\mathrm{Ag}$-rich melt and exsolution-induced inclusions of the Pt-Fe alloy phases [46].

Also, a residual melt enriched in Au likely appeared during the progressive crystallization of $\mathrm{Pt}-\mathrm{Fe}$ alloy, leading to the formation of a rim of gold $\left(\mathrm{Au}_{80}\right)$ around placer grains of Pt-Fe alloy at Florence Creek, Yukon, Canada [48]. We presume that, at Bolshoy Khailyk, this mechanism was likely significant to produce the Au-rich phase precipitated as a narrow rim $\left(\mathrm{Au}_{75}\right)$ on the $\mathrm{Pt}-\mathrm{Fe}$ alloy grain (Figure $6 \mathrm{~d}$ ). Note that the gold phase is deposited within the inner portion of the composite rim, being thus separated by the outer rim of cooperite (Figure $6 \mathrm{~d}$ ). Therefore, the gold alloy phase could not be formed by a surficial process in the placer environment.

In addition, the close association observed between Au and PGE is not unusual (e.g., in the Norilsk deposits, Russia; [37,38]; and references therein), because they are geochemically related and belong to the same group of highly siderophile elements, e.g., [49].

\subsection{Mechanism of Incorporation of Rh and Co into the Structure of Pentlandite}

Occurrences of $\mathrm{Rh}-\mathrm{Co}$-enriched grains of pentlandite hosted by the $\mathrm{Pt}-\mathrm{Au}-\mathrm{Cu}$ alloy (Figure $\mathrm{7b}$ ) have important crystallochemical implications. We infer, based on our results (Figure 11, Table 8), that $\mathrm{Rh}$ and Co display a strong sympathetic relationship. They mutually substitute for $\mathrm{Fe}$, not $\mathrm{Ni}$, and are 
incorporated into the pentlandite structure via a coupled mechanism of substitution: $\left[\mathrm{Rh}^{3+}+\mathrm{Co}^{3+}+\square\right.$ $\left.\rightarrow 3 \mathrm{Fe}^{2+}\right]$.

\subsection{Se-rich Compounds in Ophiolite-Related Associations, Western Sayans, and Their Implications}

We document the occurrence of seleniferous and rhodiferous sperrylite, i.e., $\left(\mathrm{Pt}_{0.54} \mathrm{Rh}_{0.45}\right)_{\Sigma 0.99}\left(\mathrm{As}_{1.29} \mathrm{Se}_{0.40} \mathrm{~S}_{0.31}\right)_{\Sigma 2.00}$, which forms part of the deuterically deposited assemblage (Figure $5 \mathrm{~b}$ ). This phase contains $20 \mathrm{~mol} \%$ of the sudovikovite component $\left(\mathrm{PtSe}_{2}\right)$; the latter species of PGM was also formed metasomatically in the Srednyaya Padma mine of the Velikaya Guba U-V deposit, Russian Karelia [50].

The occurrence of Se-rich sperrylite is highly unusual and even puzzling for the case of a highly primitive Os-Ir-Ru-dominant mineralization derived from an ophiolite. This is, in fact, the second occurrence of a PGE selenide in the area. The first report, from the Zolotaya River area [5], noted the presence of unnamed $\operatorname{Ir}(\mathrm{As}, \mathrm{Se}, \mathrm{S})_{2}\left(\sim 40 \mathrm{~mol} \% \mathrm{IrSe}_{2}\right)$ and Se-bearing sperrylite $(2.35 \mathrm{wt} \%$ Se) as inclusions, hosted by an Ir-dominant alloy and located at the margin of a $\mathrm{Pt}_{3} \mathrm{Fe}$-type alloy grain, respectively.

Occurrences of compounds of Se and the iridium subgroup of the PGE (IPGE: Ir, Os, and Ru), or of phases of the PGE selenides in ophiolitic or other primitive ultramafic rocks, must be extremely rare. One such occurrence, i.e., members of the $\mathrm{RuS}_{2}$ (laurite)—unnamed $\mathrm{RuSe}_{2}$ series, was recently reported from chromitite of the Pados-Tundra ultramafic complex, Kola Peninsula, Russia [51]. Normally, laurite is depleted in Se [52]. Interestingly, all of the Se-rich compounds of PGE recognized presently in association with highly primitive rocks, display an $\mathrm{AB}_{2}$-type stoichiometry: $\operatorname{Ir}(\mathrm{As}, \mathrm{Se}, \mathrm{S})_{2}, \mathrm{Pt}(\mathrm{As}, \mathrm{Se})_{2}$, $(\mathrm{Pt}, \mathrm{Rh})(\mathrm{As}, \mathrm{Se}, \mathrm{S})_{2}, \mathrm{Ru}(\mathrm{S}, \mathrm{Se})_{2}$, and $\mathrm{Ru}(\mathrm{Se}, \mathrm{S})_{2}$ ([5,51]; this study); thus, their structures are likely optimal to accommodate Se under the given conditions of crystallization.

The anomaly arises because unrealistically low values of S/Se are required to exist in the environment. The $S / S e$ ratio of the mantle is $2850-4350$, with a mean of $\sim 3250[53,54]$, and references therein. The chondritic value of this ratio is $2500 \pm 270$ [55]. Interestingly, the lowest values (190-700) were recorded in microglobules of sulfide in the Platinova Reef, Skaergaard layered complex [56]. Thus, a PGE sulfoselenide is unlikely to be stabilized instead of a pure sulfide as a primary magmatic phase in a highly primitive ultramafic rock. Besides, the PGE-Se-rich phases cannot be a consequence of a magmatic contamination, because crustal rocks have high values of S/Se: 3500 to 100,000 [54], and references therein.

At Pados-Tundra [51], the diselenide-disulfoselenide phases of Ru likely reflect a process of ultimate S-loss, causing a critical lowering of the S/Se value during a late-stage evolution of $\mathrm{H}_{2} \mathrm{O}$-bearing fluid involved in the formation of laurite-clinochlore intergrowths. An oxidizing character of this fluid was inferred cf. [57]. Sulfur is more mobile than Se in hydrothermal fluids, and is preferentially incorporated into aqueous fluids e.g., [58,59].

We believe that the occurrences of PGE selenides, derived from the ophiolitic rocks of western Sayans, result from the efficient fractional crystallization of Os-Ir-Ru-Pt-(Fe) alloys in a system that was initially reducing and closed. A buildup in levels of incompatible Se and $S$ is inferred during the progressive crystallization, then followed by a locally effective removal of $S$, which is more mobile than Se in a fluid-saturated environment associated with the zones of metasomatic alteration, especially where the sulfur is oxidized to sulfate cf. [57].

Author Contributions: The authors (A.Y.B., R.F.M., G.I.S., and S.A.S.) discussed the obtained results and wrote the article together.

Acknowledgments: We are grateful to Liana Pospelova (Novosibirsk) for her expert assistance with the WDS EMP data. We thank two anonymous reviewers and the Editorial Board members, for their comments and improvements. A.Y.B. gratefully acknowledges a partial support of this investigation by the Russian Foundation for Basic Research (project \# RFBR 16-05-00884).

Conflicts of Interest: The authors declare no conflicts of interest. 


\section{References}

1. Vysotskiy, N.K. Platinum and Areas of Its Mining; Academy of Sciences of the USSR: Moscow, Russia, 1933; 240p. (In Russian)

2. Porvatov, B.M. The mountainous wealth of Uryankhay (Uriankhai). Gold Platin. 1914, 3, 64-67. (In Russian)

3. Korovin, M.K. To the Question of the Existence of Deposits of Gold and Platinum in the Usinskiy Area; Journal of the Society of Siberian Engineers: Tomsk, Russia, 1915; Volume 7. (In Russian)

4. Krivenko, A.P.; Tolstykh, N.D.; Nesterenko, G.V.; Lazareva, E.V. Types of mineral associations of platinum metals in auriferous placers of the Altai-Sayan folded region. Russ. Geol. Geophys. 1994, 35, 70-78. (In Russian)

5. Tolstykh, N.D.; Krivenko, A.P.; Pospelova, L.N. Unusual compounds of iridium, osmium and ruthenium with selenium, tellurium and arsenic from placers of the Zolotaya River (western Sayans). Zap. Vsesoyuzn. Miner. Obshch. 1997, 126, 23-34. (In Russian)

6. Shvedov, G.I.; Nekos, V.V. PGM of a placer at the R. Bolshoy Khailyk (western Sayans). Geol. Resour. Krasnoyarskiy Kray 2008, 9, 240-248. (In Russian)

7. Aleksandrov, G.P.; Gulyaev, Y.S. The Geological Map of the USSR (Scale 1:200,000; M-46-III); The Western Sayan Series; NEDRA: Moscow, Russia, 1966.

8. Barkov, A.Y.; Shvedov, G.I.; Martin, R.F. PGE-(REE-Ti)-rich micrometer-sized inclusions, mineral associations, compositional variations, and a potential lode source of platinum-group minerals in the Sisim Placer Zone, Eastern Sayans, Russia. Minerals 2018, 8, 181. [CrossRef]

9. Harris, D.C.; Cabri, L.J. Nomenclature of platinum-group-element alloys: Review and revision. Can. Mineral. 1991, 29, 231-237.

10. Nash, P.; Singleton, M.F. The Ni-Pt (Nickel-Platinum) system. Bull. Alloy Phase Diagr. 1989, 10, $258-262$. [CrossRef]

11. McDonald, A.M.; Proenza, J.A.; Zaccarini, F.; Rudashevsky, N.S.; Cabri, L.J.; Stanley, C.J.; Rudashevsky, V.N.; Melgarejo, J.C.; Lewis, J.F.; Longo, F.; et al. Garutiite, (Ni,Fe,Ir), a new hexagonal polymorph of native Ni from Loma Peguera, Dominican Republic. Eur. J. Mineral. 2010, 22, 293-304. [CrossRef]

12. Mochalov, A.G.; Dmitrenko, G.G.; Rudashevskii, N.S.; Zhernovskii, V.; Boldyreva, M.M. Hexaferrum (Fe,Ru), (Fe,Os), (Fe,Ir)—A new mineral. Zap. Vseross. Miner. Obshch. 1998, 127, 41-51. (In Russian)

13. Cabri, L.J.; Aiglsperger, T. A review of hexaferrum based on new mineralogical data. Mineral. Mag. 2018, 1-16. [CrossRef]

14. Barkov, A.Y.; Martin, R.F.; Halkoaho, T.A.A.; Poirier, G. The mechanism of charge compensation in Cu-Fe-PGE thiospinels from the Penikat layered intrusion, Finland. Am. Mineral. 2000, 85, 694-697. [CrossRef]

15. Berlincourt, L.E.; Hummel, H.H.; Skinner, B.J. Phases and phase relations of the platinum-group elements. In Platinum-group elements: Mineralogy, Geology, Recovery; Cabri, L.J., Ed.; Canadian Institute of Mining, Metallurgy and Petroleum: Westmount, QC, Canada, 1981; Special Volume 23, pp. 21-43.

16. Tolstykh, N.D.; Telegin, Yu.M.; Kozlov, A.P. Platinum mineralization of the Svetloborsky and Kamenushinsky massifs (Urals Platinum Belt). Russ. Geol. Geophys. 2011, 52, 603-619. [CrossRef]

17. Razin, L.V.; Rudashevskiy, N.S.; Sidorenko, G.A. Tolovkite, IrSbS, a new sulfoantimonide of iridium from the northeastern USSR. Int. Geol. Rev. 1982, 24, 849-854. [CrossRef]

18. Barkov, A.Y.; Tolstykh, N.D.; Shvedov, G.I.; Martin, R.F. Ophiolite-related associations of platinum-group minerals at Rudnaya, western Sayans, and Miass, southern Urals, Russia. Mineral. Mag. 2018. [CrossRef]

19. Cabri, L.J.; Laflamme, J.G.; Stewart, J.M. Platinum-group minerals from Onverwacht; II, Platarsite, a new sulfarsenide of platinum. Can. Mineral. 1977, 15, 385-388.

20. Augé, T.; Legendre, O. Platinum-group element oxides from the Pirogues ophiolitic mineralization, New Caledonia; origin and significance. Econ. Geol. 1994, 89, 1454-1468. [CrossRef]

21. Melcher, F.; Oberthür, T.; Lodziak, J. Modification of detrital platinum-group minerals from the eastern Bushveld complex, South Africa. Can. Mineral. 2005, 43, 1711-1734. [CrossRef]

22. Oberthür, T.; Melcher, F.; Gast, L.; Wöhrl, C.; Lodziak, J. Detrital platinum-group minerals in rivers draining the eastern Bushveld complex, South Africa. Can. Mineral. 2004, 42, 563-582. [CrossRef]

23. Oberthür, T.; Weiser, W.; Melcher, F. Alluvial and eluvial platinum-group minerals from the Bushveld complex, South Africa. S. Afr. J. Geol. 2014, 117, 255-274. [CrossRef] 
24. Hattori, K.H.; Takahashi, Y.; Augé, T. Mineralogy and origin of oxygen-bearing platinum-iron grains based on an X-ray absorption spectroscopy study. Am. Mineral. 2010, 95, 622-630. [CrossRef]

25. Barkov, A.Y.; Shvedov, G.I.; Polonyankin, A.A.; Martin, R.F. New and unusual Pd-Tl-bearing mineralization in the Anomal'nyi deposit, Kondyor concentrically zoned complex, northern Khabarovskiy kray, Russia. Mineral. Mag. 2017, 81, 679-688. [CrossRef]

26. Barkov, A.Y.; Fleet, M.E.; Martin, R.F.; Halkoaho, T.A.A. New data on "bonanza"-type PGE mineralization in the Kirakkajuppura PGE deposit, Penikat layered complex, Finland. Can. Mineral. 2005, 43, 1663-1686. [CrossRef]

27. Tolstykh, N.D.; Krivenko, A.P.; Lavrent'ev, Y.G.; Tolstykh, O.N.; Korolyuk, V.N. Oxides of the Pd-Sb-Bi system from the Chiney massif (Aldan Shield, Russia). Eur. J. Miner. 2000, 12, 431-440. [CrossRef]

28. Cabri, L.J.; Laflamme, J.H.G. Analyses of minerals containing platinum-group elements. In Platinum-group elements: Mineralogy, Geology, Recovery; Cabri, L.J., Ed.; Canadian Institute of Mining, Metallurgy and Petroleum: Westmount, QC, Canada, 1981; Special Volume 23, pp. 151-173.

29. Törnroos, R.; Vuorelainen, Y. Platinum-group metals and their alloys in nuggets from alluvial deposits in Finnish Lapland. Lithos 1987, 20, 491-500. [CrossRef]

30. Johan, Z.; Ohnenstetter, M.; Fischer, M.; Amosse, J. Platinum-group minerals from the Durance River alluvium, France. Mineral. Petrol. 1990, 42, 287-306. [CrossRef]

31. Nekrasov, I.Y.; Lennikov, A.M.; Zalishchak, B.L.; Oktyabrsky, R.A.; Ivanov, V.V.; Sapin, V.I.; Taskaev, V.I. Compositional variations in platinum-group minerals and gold, Konder alkaline-ultrabasic massif, Aldan Shield, Russia. Can. Mineral. 2005, 43, 637-654. [CrossRef]

32. Chen, K.; Yu, T.; Zhang, Y.; Peng, Z. Tetra-auricupride, CuAu, discovered in China. Sci. Geol. Sin. 1982. 17, 111-116. (In Chinese, English Abstract)

33. Yu, Z. New data for daomanite and hongshiite. Acta Geol. Sin. 2001, 75, 458-466.

34. Shah, A.; Latif-Ur-Rahman, L.-U.; Qureshi, R.; Zia-Ur-Rehman, Z.-U. Synthesis, characterization and applications of bimetallic ( $\mathrm{Au}-\mathrm{Ag}, \mathrm{Au}-\mathrm{Pt}, \mathrm{Au}-\mathrm{Ru})$ alloy nanoparticles. Rev. Adv. Mater. Sci. 2012, 30, 133-149.

35. Evstigneeva, T.L.; Nekrasov, I.Y. Conditions of the formation of tin-bearing platinum-group minerals in the system Pd-Cu-Sn and its partial cross sections. In Tin in Magmatic and Postmagmatic Processes; Nekrasov, I.Y., Ed.; Nauka Press: Moscow, Russia, 1984; pp. 143-169. (In Russian)

36. Evstigneeva, T.L.; Genkin, A.D. Cabriite $\mathrm{Pd}_{2} \mathrm{SnCu}$, a new species in mineral group of palladium, tin and copper compounds. Can. Mineral. 1983, 21, 481-487.

37. Barkov, A.Y.; Martin, R.F.; Poirier, G.; Tarkian, M.; Pakhomovskii, Y.A.; Men'shikov, Y.P. Tatyanaite, a new platinum-group mineral, the Pt analogue of taimyrite, from the Noril'sk complex (northern Siberia, Russia). Eur. J. Mineral. 2000, 12, 391-396. [CrossRef]

38. Barkov, A.Y.; Martin, R.F. Compositional variations in natural intermetallic compounds of Pd, Pt, $\mathrm{Cu}$, and $\mathrm{Sn}$ : New data and implications. Can. Mineral. 2016, 54, 453-460. [CrossRef]

39. Makovicky, E.; Makovicky, M.; Rose-Hansen, J. The system Fe-Rh-S at $900^{\circ}$ and $500{ }^{\circ}$ C. Can. Mineral. 2002, 40, 519-526. [CrossRef]

40. Makovicky, M.; Makovicky, E.; Rose-Hansen, J. Experimental studies on the solubility and distribution of platinum group elements in base metal sulfides in platinum deposits. In Metallogeny of Basic and Ultrabasic Rocks; Gallagher, M.J., Ixer, R.A., Neary, C.R., Prichard, H.M., Eds.; Institution of Mining and Metallurgy: London, UK, 1986; pp. 415-425.

41. Genkin, A.D.; Laputina, I.P.; Muravitskaya, G.N. Ruthenium- and rhodium-containing pentlandite-An indicator of hydrothermal mobilization of platinum metals. Int. Geol. Rev. 1976, 18, 723-728. [CrossRef]

42. Merkle, R.K.W.; von Gruenewaldt, G. Compositional variation of Co-rich pentlandite: Relation to the evolution of the upper zone of the western Bushveld complex, South Africa. Can. Mineral. 1986, 24, 529-546.

43. Junge, M.; Wirth, R.; Oberthür, T.; Melcher, F.; Schreiber, A. Mineralogical siting of platinum-group elements in pentlandite from the Bushveld Complex, South Africa. Miner. Depos. 2015, 50, 41-54. [CrossRef]

44. Barkov, A.Y.; Fleet, M.E.; Nixon, G.T.; Levson, V.M. Platinum-group minerals from five placer deposits in British Columbia, Canada. Can. Mineral. 2005, 43, 1687-1710. [CrossRef]

45. Barkov, A.Y.; Fleet, M.E.; Martin, R.F.; Feinglos, M.N.; Cannon, B. Unique W-rich alloy of Os and Ir and associated Fe-rich alloy of Os, Ru, and Ir from California. Am. Mineral. 2006, 91, 191-195. [CrossRef] 
46. Barkov, A.Y.; Martin, R.F.; Shi, L.; Feinglos, M.N. New data on PGE alloy minerals from a very old collection (probably 1890s), California. Am. Mineral. 2008, 93, 1574-1580. [CrossRef]

47. Klein, F.; Bach, W. Fe-Ni-Co-O-S phase relations in peridotite-seawater interactions. J. Petrol. 2009, 50, 37-59. [CrossRef]

48. Barkov, A.Y.; Martin, R.F.; LeBarge, W.; Fedortchouk, Y. Grains of Pt-Fe alloy and inclusions in a Pt-Fe alloy from Florence creek, Yukon, Canada: Evidence for mobility of Os in a Na- $\mathrm{H}_{2} \mathrm{O}-\mathrm{Cl}$-rich fluid. Can. Mineral. 2008, 46, 343-360. [CrossRef]

49. O’Driscoll, B.; González-Jiménez, J.M. Petrogenesis of the platinum-group minerals. Rev. Mineral. Geochem. 2015, 81, 489-578. [CrossRef]

50. Polekhovskiy, Y.S.; Tarasova, I.P.; Nesterov, A.P.; Pakhomovskiy, Y.A.; Bakhchisaraitsev, A.Y. Sudovikovite $\mathrm{PtSe}_{2}$-a new platinum selenide from a metasomic rock of southern Karelia. Dokl. Akad. Nauk 1997, 354, 82-85. (In Russian)

51. Barkov, A.Y.; Nikiforov, A.A.; Tolstykh, N.D.; Shvedov, G.I.; Korolyuk, V.N. Compounds of Ru-Se-S, alloys of Os-Ir, framboidal Ru nanophases and laurite-clinochlore intergrowths in the Pados-Tundra complex, Kola Peninsula, Russia. Eur. J. Mineral. 2017, 29, 613-622. [CrossRef]

52. Hattori, K.H.; Cabri, L.J.; Johanson, B.; Zientek, M.L. Origin of placer laurite from Borneo: Se and As contents, and S isotopic compositions. Mineral. Mag. 2004, 68, 353-368. [CrossRef]

53. Lorand, J.-P.; Alard, O.; Luguet, A.; Keays, R.R. Sulfur and selenium systematics of the subcontinental lithospheric mantle: Inferences from the Massif Central xenolith suite (France). Geochim. Cosmochim. Acta 2003, 67, 4137-4151. [CrossRef]

54. Smith, J.W.; Holwell, D.A.; McDonald, I.; Boyce, A.J. The application of S isotopes and S/Se ratios in determining ore-forming processes of magmatic Ni-Cu-PGE sulfide deposits: A cautionary case study from the northern Bushveld Complex. Ore Geol. Rev. 2016, 73, 148-174. [CrossRef]

55. Dreibus, G.; Palme, H.; Spettek, B.; Zipfel, J.; Wänke, H. Sulfur and selenium in chondritic meteorites. Meteoritics 1995, 30, 439-445. [CrossRef]

56. Holwell, D.A.; Keays, R.R.; McDonald, I.; Williams, M.R. Extreme enrichment of Se, Te, PGE and Au in $\mathrm{Cu}$ sulfide microdroplets: Evidence from LA-ICP-MS analysis of sulfides in the Skaergaard intrusion, east Greenland. Contrib. Mineral. Petrol. 2015, 170, 53. [CrossRef]

57. Simon, G.; Kesler, S.E.; Essene, E.J. Phase relations among selenides, tellurides, and oxides: II. Applications to selenide-bearing ore deposits. Econ. Geol. 1997, 92, 468-484. [CrossRef]

58. Ewers, G.R. Experimental hot water-rock interactions and their significance to natural hydrothermal systems in New Zealand. Geochim. Cosmochim. Acta 1977, 41, 143-150. [CrossRef]

59. Howard, J.H. Geochemistry of selenium: Formation of ferroselite and selenium behavior in the vicinity of oxidizing sulfide and uranium deposits. Geochim. Cosmochim. Acta 1977, 41, 1665-1678. [CrossRef] 